\title{
The Sources of Real Exchange Rate Fluctuations in Sub-Saharan Africa
}

\author{
Yaya Sissoko \\ Indiana University of Pennsylvania, Indiana P.A., USA
}

\begin{abstract}
This paper looks into the sources of real exchange rate fluctuations in Sub-Saharan African (SSA) countries. This issue is investigated in a context of small open economies of SSA using a structural Vector Auto Regression (VAR) approach with limited capital mobility and a weak-banking system in Africa. A structural VAR implies long run restrictions of a small open economy model to identify the shocks. The results suggest that the real exchange rate (RER) variability is mostly driven by real disturbances in both the "Communauté Financière Africaine" (CFA) and non-CFA countries at long term forecasting horizons. The findings show evidence that nominal shocks seem to matter more in the non-CFA countries in the short run in explaining RER and price level fluctuations as a result of the diverse fiscal and monetary policies in the non-CFA countries in contrast to the CFA countries.
\end{abstract}

Keywords: business cycles, real exchange rate, sub-Saharan Africa, time series models

\section{Introduction}

The analysis of the sources of fluctuations in real exchange rates gained great interest after the collapse of the Bretton Woods system ${ }^{1}$ in 1971 . Most economists believe that a flexible exchange rate regime causes macroeconomic variables to be more volatile. Mussa (1986) argues that sluggish price adjustment must play a central role in explaining the movements in nominal and real exchange rates in the short run. Mussa's influential paper points out a higher variance of real exchange rates for the post Bretton Woods era.

Cumby and Huizinga (1991), and more importantly, Dibooğlu and Koray (2001) investigate the predictability of real exchange rate changes. They also decompose changes in real exchange rates into transitory and permanent components. They find real exchange rate changes to be predictable and sustained for the German Mark, the Japanese Yen and the US Dollar. Clarida and Gali (1994) find that demand shocks explain most of the fluctuations in real exchange rates since the collapse of Bretton Woods. Clarida and Gali estimate the open macroeconomic model in the spirit of Dornbusch (1976) and Obstfeld (1985) using a structural vector autoregression (VAR) model to identify the shocks to demand, supply, and money. Supply shocks have

\footnotetext{
Yaya Sissoko, Ph.D., Associate Professor of Economics, Department of Economics, Indiana University of Pennsylvania. Correspondence concerning this article should be addressed to Yaya Sissoko, Department of Economics, Indiana University of Pennsylvania, Indiana, PA 15705, USA. E-mail: ysissoko@iup.edu.

1 The Bretton Woods Agreement (BWA) of July 1944 in New Hampshire established a postwar international monetary system - the International Monetary Fund (IMF) and the International Bank for Reconstruction and Development known as the World Bank - of convertible currencies, fixed exchange rates and free trade. The BWA leads later on in 1947 to the creation of the General Agreement on Tariffs and Trade (GATT) known as the World Trade Organization.
} 
little impact on the real exchange rate fluctuations.

Lastrapes (1991) empirically investigates the sources of fluctuations in real and nominal exchange rates in the G-6 countries consisting of the United States, Germany, the United Kingdom, Japan, Italy, and Canada. He decomposes the exchange rates into transitory and permanent components. Lastrapes finds that real disturbances such as resource endowments or technology preferences dominate nominal shocks such as money supply in explaining real exchange rate fluctuations at short and long term forecasting horizons. That is, only real shocks have permanent effects on the real and nominal exchange rates. Enders and Lee (1997) examine the fluctuations of real and nominal exchange rates induced by real and nominal factors between the United States and Canada on one hand and Japan and Germany on the other hand. They conclude that the variability of exchange rates is driven by real demand disturbances and not by real supply shocks in the countries considered in the study. They also find little evidence of exchange rate overshooting. Moreover, Dibooğlu and Kutan (2001) investigate the sources of real exchange rate fluctuations in the transition economies of Poland and Hungary. They find mixed results. Real shocks are the main sources of real exchange rate fluctuations in Hungary while nominal disturbances explain some of the variation of real exchange rates in Poland. That is, nominal shocks have a great impact on the real exchange rate fluctuations in Poland, but, in contrast, they do not matter in explaining the variability of real exchange rates in Hungary.

Messe and Rogoff (1988) find that the main sources of fluctuations in real exchange rates are real shocks such as productivity disturbances. Their sample covers the modern floating rate period from 1973 to 1988 . Flood and Hodrick (1986) argue that output volatility is higher under a regime of fixed exchange rates than during a flexible exchange rate regime. ${ }^{2}$ Most of the earlier studies on the sources of fluctuations of real exchange rates cover the industrialized nations or developed countries. Chadha and Prasad (1994) investigate the sources of real exchange rate fluctuations in Japan from 1951 to 1996. They conclude that relative nominal and real demand shocks are the main determinants in the fluctuations in real exchange rates in Japan.

Elbadawi and Soto (1997) analyze the relationship between real exchange rates and the macroeconomic adjustment in Sub-Saharan Africa (SSA) and other developing countries. Capital flows and foreign direct investment are important factors in the long run fluctuations of real exchange rates in developing countries. Sekkat and Varoudakis (2000) find that exchange rate management matters for the export performance in SSA countries. Savvides (1996) analyzes the variability of nominal and real exchange rates in SSA countries. Both the "Communauté financière Africaine" $\left(\mathrm{CFA}^{3}\right)$ and non-CFA countries experience increased variability of nominal and real exchange rates during the modern flexible period. CFA countries record lower nominal exchange rate variability in comparison to non-CFA countries.

The objective of this paper is to determine the main determinants of real exchange rate (RER) fluctuations in SSA countries. The contribution of the study is to show that RER variability in SSA countries is driven by nominal or real demand shocks or supply disturbances. SSA countries experience both the fixed and flexible exchange rate regimes. The CFA countries adopt the fixed regime while the non-CFA countries maintain a

2 Also see Gerlach (1988) for similar findings.

3 The CFA stands for "Communauté Financière Africaine" in West Africa and "Cooperation Financière en Afrique Centrale" in Central Africa. The CFA Franc zone consists of 15 countries with eight in West Africa (Bénin, Burkina Faso, Côte d'Ivoire, Guinée Bissau, Mali, Niger, Sénégal and Togo) and six in Central Africa (Cameroon, Central African Republic, Chad, Congo and Gabon) and the Islamic Republic of Comoros. France colonized the CFA Franc countries. 
flexible regime. The findings of the study will provide evidence of policy implications for the SSA countries.

This paper is organized as follows. The second section presents the data and the methodology. The third section discusses the empirical results while the last section concludes the study.

\section{Data Analysis and Methodology}

This study considers bivariate decompositions, which include the Real Exchange Rate (RER) and the price level measured in natural logarithms. The RER series is computed using the Nominal Exchange Rates (NER) times Foreign Prices divided by Domestic Prices. NER are proxied by national currency per Special Drawing Rights (SDR). Consumer Price Index (CPI) and the inflation rates of the G-7 are used, respectively, as proxies for Domestic and Foreign Prices.

The study covers 30 SSA countries from both the CFA Franc and the non-CFA Franc zones. The CFA countries covered in the study include Benin, Burkina Faso, Cameroon, Central African Republic, Chad, Congo, Côte D'Ivoire, Gabon, Mali, Niger, Senegal, and Togo. The non-CFA countries are Botswana, Burundi, Ethiopia, Gambia, Ghana, Kenya, Lesotho, Madagascar, Malawi, Mauritius, Nigeria, Rwanda, South African Republic, Swaziland, Tanzania, Uganda, Zambia, and Zimbabwe. The sample covers the period from 1966 to 2006 for both the CFA and the non-CFA countries. All the data are annual observations taken from the IFS CD-ROM published by the International Monetary Fund (IMF).

The sources of real exchange fluctuations in SSA countries are investigated using a structural VAR framework with limited capital mobility and a weak-banking system in Africa. This methodology follows Blanchard and Quah (1989) for distinguishing temporary from permanent disturbances using a pair of time series variables. Clarida and Gali (1994) extend it to identify nominal or real demand shock or supply shock using long run restrictions.

Consider a model of an infinite moving average of a vector of variables $X_{t}$ and an equal numbers of shocks $\varepsilon_{t}$ written as follows using a lag operator $L$ :

$$
\begin{aligned}
X_{t} & =A_{0} \varepsilon_{t}+A_{1} \varepsilon_{t-1}+A_{2} \varepsilon_{t-2}+A_{3} \varepsilon_{t-3} \cdots \\
& =\sum_{i=0}^{\infty} L^{i} A_{i} \varepsilon_{t}
\end{aligned}
$$

where $A_{i}$ represents the matrix of the impulse response functions of the shocks to the elements of $X$. Moreover, let $X_{t}$ consist of the changes in Real Exchanges Rates $\left(\Delta q_{t}\right)$ and Price Level $\left(\Delta p_{t}\right)$, and $\varepsilon_{t}$ consists of real shocks $\left(\varepsilon_{t}^{r}\right)$ and nominal shocks $\left(\varepsilon_{t}^{n}\right)$. Real and nominal shocks are assumed to be orthogonal. For instance, technological or productivity changes may be the source of RER variability while nominal shocks reflect changes in nominal exchange rates (reevaluation or devaluation) or nominal money supply changes. Since the vector $\left[\Delta q_{t} \Delta p_{t}\right]^{\prime}$ is stationary, the model can written as an infinite moving average of structural shocks:

$$
\left|\begin{array}{c}
\Delta q_{t} \\
\Delta p_{t}
\end{array}\right|=\left|\begin{array}{ll}
A_{11}(L) & A_{12}(L) \\
A_{21}(L) & A_{22}(L)
\end{array}\right|\left|\begin{array}{c}
\varepsilon_{t}^{r} \\
\varepsilon_{t}^{n}
\end{array}\right|
$$

where $q_{t}$ and $p_{t}$ are the natural logarithms of real exchange rates and prices and $A_{i j}$ are polynomials in the lag operator, $L$.

This framework implies that real shocks have permanent effects on real exchange rates, but nominal shocks 
have only temporary effects ${ }^{4}$. That is, nominal shocks have no long-run effect on the real exchange rate. Therefore, the cumulative effect of nominal shocks on the variability or change in real exchange rate, $\Delta q_{t}$ must be zero. This implies the restriction:

$$
\sum_{k=0}^{\infty} a_{12}(k)=0
$$

where $a_{i j}$ is the $k$ th coefficient in $A_{i j}(L)$. Moreover, there is no restriction of real and nominal shocks on the price level.

Combine equations (2) and (3) and estimate them using a finite order VAR written as:

$$
\begin{aligned}
X_{t} & =B_{1} X_{t-1}+B_{2} X_{t-2}+\ldots+B_{n} X_{t-n}+e_{t} \\
& =[I-B(L)]^{-1} e_{t} \\
& =\left[I+B(L)+B(L)^{2}+\ldots\right] e_{t} \\
& =e_{t}+D_{1} e_{t-1}+D_{2} e_{t-2}+D_{3} e_{t-3}+\ldots
\end{aligned}
$$

or:

$$
X_{t}=\sum_{i=0}^{\infty} D_{t} e_{t-i}=D(L) e_{t}
$$

where $D_{0}=I ; X_{t}$ consists of $\Delta q_{t}$ and $\Delta p_{t}$, and $e_{t}$ represents the residuals of a regression of lagged values of $\Delta q_{t}$ and $\Delta p_{t}$ on their current values. Note that $e_{q t}$ is the residual associated with $\Delta q_{t}$ and $e_{p t}$ is the one associated with $\Delta p_{t} . B$ represents the coefficients to be estimated. Equation (5) provides the restrictions needed to identify the shocks. This methodology allows for decomposition of a series into its temporary and permanent components.

The VAR is specified properly by testing the data for times series properties. The Augmented Dickey-Fuller (ADF) and Kwiathowski-Phillips-Schmitt-Shin (KPSS) test statistics are used to test the data for unit roots and stationarity. Table 1 reports the results of the ADF tests while Table 2 shows the results of the KPSS statistic tests.

The ADF test statistics also indicate that the variables are stationary in the first differences at the significance level of 5 percent. This stationarity makes the use of a VAR model appropriate. Moreover, the KPSS test statistics confirm the results of the ADF test statistics. That is, the null hypothesis of the KPSS test is accepted at the first differences at the 10 percent significance level.

\section{Empirical Results}

The dynamic effects of the nominal and real shocks can be analyzed through the Impulse Response Functions (IRF) and Variance Decompositions (VD). The results of the IRF for selective CFA and Non-CFA countries are shown on several graphs (see Figures 1-30). Each graph displays the dynamic response of the real exchange rates or the prices to the real shocks $\left(\varepsilon_{t}^{r}\right)$ and to the nominal disturbances $\left(\varepsilon_{t}^{n}\right)$.

The real shocks seem to be the major source of real exchange fluctuations in the CFA and non-CFA countries. The movements in the price level are driven by nominal disturbances in Sub-Saharan African countries. As presumed by the model, nominal shocks have only temporary effects on the real exchange rates.

${ }^{4}$ See Bayoumi and Eichengreen (1994), and Dibooğlu and Kutan (2001) for further analyses. 
In the CFA countries at short-term forecasting horizons (1 year), one standard deviation of real shocks causes real exchange rate to decrease by 60 percent but have a mixed result on the price level. Indeed, real shocks cause prices to increase 5 percent in almost half of the CFA countries and decrease 2.5 percent in the other half. The real disturbances still have a major influence on the real exchange rate after one year, but the effects on the price level die out. Moreover, one standard deviation of nominal shocks induces prices to fall by 7 percent the first year but increase the real exchange rates by less than 1 percent in most of the CFA countries. Within 3 to 5 years on average, these responses decay towards zero for most of the CFA countries.

On the other hand, one standard deviation of real shocks leads to a 70 percent decrease in the real exchange rates the first year and a 2 percent increase in the price level for most of the non-CFA countries. Nominal shocks have a great impact on the prices. Indeed, prices increase by 12 percent on average in the non-CFA countries in response to nominal disturbances. Furthermore, the real exchange rates appreciate for by 2 percent at the same time. The contemporaneous responses of nominal shocks decay on average towards zero within four to eight years for both the real exchange rates and the price level.

Table 1

Unit Root Tests-ADF Test

\begin{tabular}{|c|c|c|c|c|}
\hline \multicolumn{5}{|c|}{ ADF statistic ${ }^{\mathrm{a}}$} \\
\hline \multirow{3}{*}{ Country } & \multicolumn{2}{|c|}{ Level $^{\mathrm{b}}$} & \multicolumn{2}{|c|}{ First difference $^{\mathrm{b}}$} \\
\hline & $q$ & $p$ & $q$ & $p$ \\
\hline & \multicolumn{4}{|c|}{ CFA countries } \\
\hline Lag Length & 2 & 2 & 2 & 2 \\
\hline Benin & -2.862 & -2.310 & -6.734 & -3.797 \\
\hline Lag Length & 2 & 1 & 2 & 1 \\
\hline Burkina Faso & -3.242 & -1.569 & -6.627 & -6.232 \\
\hline Lag Length & 2 & 1 & 2 & 1 \\
\hline Cameroon & -2.861 & -1.825 & -6.739 & -3.554 \\
\hline Lag Length & 2 & 1 & 2 & 1 \\
\hline Chad & -3.228 & -0.825 & -6.576 & -3.997 \\
\hline Lag Length & 1 & 1 & 1 & 1 \\
\hline C.A.R ${ }^{\mathrm{c}}$ & -2.555 & -2.162 & -6.929 & -3.995 \\
\hline Lag Length & 2 & 1 & 2 & 1 \\
\hline Congo & -2.990 & -2.500 & -4.693 & -6.073 \\
\hline Lag Length & 2 & 1 & 2 & 1 \\
\hline Cote D'Ivoire & -3.091 & -2.340 & -4.737 & -3.641 \\
\hline Lag Length & 1 & 2 & 1 & 2 \\
\hline Gabon & -3.223 & -1.239 & -6.832 & -4.253 \\
\hline Lag Length & 2 & 1 & 2 & 1 \\
\hline Mali & -3.371 & -1.863 & -5.205 & -4.076 \\
\hline Lag Length & 1 & 1 & 1 & 1 \\
\hline Niger & -2.816 & -1.735 & -6.853 & -4.015 \\
\hline Lag Length & 1 & 1 & 1 & 1 \\
\hline Senegal & -2.888 & -2.097 & -6.959 & -3.613 \\
\hline Lag Length & 1 & 1 & 1 & 1 \\
\hline Togo & -3.109 & -2.255 & -6.773 & -3.736 \\
\hline
\end{tabular}


(Table 1 continued)

\begin{tabular}{|c|c|c|c|c|}
\hline \multicolumn{5}{|c|}{ ADF statistic ${ }^{a}$} \\
\hline \multirow{3}{*}{ Country } & \multicolumn{2}{|c|}{ Level $^{b}$} & \multicolumn{2}{|c|}{ First difference $^{b}$} \\
\hline & $q$ & $p$ & $q$ & $p$ \\
\hline & \multicolumn{4}{|c|}{ Non-CFA countries } \\
\hline Lag Length & 1 & 1 & 1 & 1 \\
\hline Botswana & -3.213 & -2.594 & -7.088 & -4.947 \\
\hline Lag Length & 1 & 1 & 1 & 1 \\
\hline Burundi & -3.183 & -2.554 & -7.083 & -3.572 \\
\hline Lag Length & 1 & 1 & 1 & 1 \\
\hline Ethiopia & -3.140 & -2.506 & -6.273 & -4.054 \\
\hline Lag Length & 1 & 2 & 1 & 2 \\
\hline Gambia & -3.323 & -2.842 & -6.937 & -4.786 \\
\hline Lag Length & 1 & 2 & 1 & 2 \\
\hline Ghana & -3.188 & -2.390 & -5.672 & -3.664 \\
\hline Lag Length & 2 & 2 & 2 & 2 \\
\hline Kenya & -3.270 & -2.602 & -5.992 & -4.103 \\
\hline Lag Length & 2 & 1 & 2 & 1 \\
\hline Lesotho & -3.024 & -0.869 & -5.441 & -4.144 \\
\hline Lag Length & 1 & 2 & 1 & 2 \\
\hline Madagascar & -2.716 & -1.550 & -7.020 & -4.297 \\
\hline Lag Length & 1 & 2 & 1 & 2 \\
\hline Malawi & -2.361 & -0.291 & -6.914 & -4.735 \\
\hline Lag Length & 1 & 1 & 1 & 1 \\
\hline Mauritius & -3.057 & -2.208 & -6.966 & -3.562 \\
\hline Lag Length & 2 & 2 & 2 & 2 \\
\hline Nigeria & -3.273 & -1.959 & -5.417 & -4.354 \\
\hline Lag Length & 1 & 1 & 1 & 1 \\
\hline Rwanda & -3.336 & -2.926 & -6.933 & -3.919 \\
\hline Lag Length & 1 & 2 & 1 & 2 \\
\hline South Africa & -3.351 & -2.050 & -6.821 & -3.759 \\
\hline Lag Length & 1 & 1 & 1 & 1 \\
\hline Swaziland & -2.648 & -2.023 & -6.582 & -3.952 \\
\hline Lag Length & 1 & 1 & 1 & 1 \\
\hline Tanzania & 3.252 & -2.319 & -6.491 & -4.891 \\
\hline Lag Length & 1 & 2 & 1 & 2 \\
\hline Uganda & -2.753 & -1.940 & -6.246 & -4.327 \\
\hline Lag Length & 1 & 2 & 1 & 2 \\
\hline Zambia & -3.338 & -2.407 & -6.563 & -3.769 \\
\hline Lag Length & 1 & 1 & 1 & 1 \\
\hline Zimbabwe & -1.262 & -0.670 & -7.228 & -4.378 \\
\hline \multicolumn{5}{|c|}{ Critical values for $T=50^{\mathrm{d}}$} \\
\hline $10 \%$ & -3.18 & & & \\
\hline $5 \%$ & -3.50 & & & \\
\hline $1 \%$ & -4.15 & & & \\
\hline
\end{tabular}


Table 2

Unit Root Tests-KPSS Test

\begin{tabular}{|c|c|c|c|c|c|}
\hline \multicolumn{6}{|c|}{ KPSS test ${ }^{\mathrm{a}}$} \\
\hline \multirow{3}{*}{ Country } & \multicolumn{2}{|c|}{ Level } & \multicolumn{2}{|c|}{ First difference } & \multirow[b]{2}{*}{$p$} \\
\hline & Lag $^{\mathrm{b}}$ & $q$ & $p$ & $q$ & \\
\hline & \multicolumn{4}{|c|}{ CFA countries } & \\
\hline Benin & 2 & 0.121 & 0.249 & 0.053 & 0.092 \\
\hline Burkina Faso & 2 & 0.175 & 0.143 & 0.080 & 0.103 \\
\hline Cameroon & 2 & 0.186 & 0.154 & 0.070 & 0.092 \\
\hline Chad & 2 & 0.120 & 0.346 & 0.060 & 0.070 \\
\hline C.A. $R^{c}$ & 2 & 0.133 & 0.301 & 0.054 & 0.072 \\
\hline Congo & 2 & 0.207 & 0.159 & 0.081 & 0.138 \\
\hline Cote D'Ivoire & 2 & 0.184 & 0.151 & 0.075 & 0.119 \\
\hline Gabon & 2 & 0.159 & 0.210 & 0.069 & 0.095 \\
\hline Mali & 2 & 0.153 & 0.352 & 0.064 & 0.143 \\
\hline Niger & 2 & 0.140 & 0.250 & 0.062 & 0.075 \\
\hline Senegal & 2 & 0.135 & 0.253 & 0.051 & 0.089 \\
\hline \multirow[t]{2}{*}{ Togo } & 2 & 0.210 & 0.121 & 0.071 & 0.067 \\
\hline & \multicolumn{5}{|c|}{ Non-CFA countries } \\
\hline Botswana & 2 & 0.137 & 0.145 & 0.063 & 0.138 \\
\hline Burundi & 2 & 0.189 & 0.172 & 0.055 & 0.118 \\
\hline Ethiopia & 2 & 0.151 & 0.124 & 0.068 & 0.073 \\
\hline Gambia & 2 & 0.220 & 0.213 & 0.060 & 0.117 \\
\hline Ghana & 2 & 0.133 & 0.214 & 0.072 & 0.142 \\
\hline Kenya & 2 & 0.235 & 0.302 & 0.057 & 0.115 \\
\hline Lesotho & 2 & 0.133 & 0.137 & 0.048 & 0.128 \\
\hline Madagascar & 2 & 0.156 & 0.311 & 0.042 & 0.077 \\
\hline Malawi & 2 & 0.120 & 0.212 & 0.045 & 0.145 \\
\hline Mauritius & 2 & 0.224 & 0.131 & 0.046 & 0.070 \\
\hline Nigeria & 2 & 0.134 & 0.335 & 0.057 & 0.073 \\
\hline Rwanda & 2 & 0.212 & 0.197 & 0.071 & 0.083 \\
\hline South Africa & 2 & 0.224 & 0.294 & 0.068 & 0.105 \\
\hline Swaziland & 2 & 0.309 & 0.261 & 0.074 & 0.113 \\
\hline Tanzania & 2 & 0.120 & 0.341 & 0.043 & 0.143 \\
\hline Uganda & 2 & 0.166 & 0.256 & 0.048 & 0.107 \\
\hline Zambia & 2 & 0.153 & 0.342 & 0.063 & 0.110 \\
\hline Zimbabwe & 2 & 0.363 & 0.359 & 0.042 & 0.069 \\
\hline \multicolumn{6}{|c|}{ Critical values for $T=40$} \\
\hline $10 \%$ & 0.119 & & & & \\
\hline $5 \%$ & 0.146 & & & & \\
\hline $1 \%$ & 0.216 & & & & \\
\hline
\end{tabular}




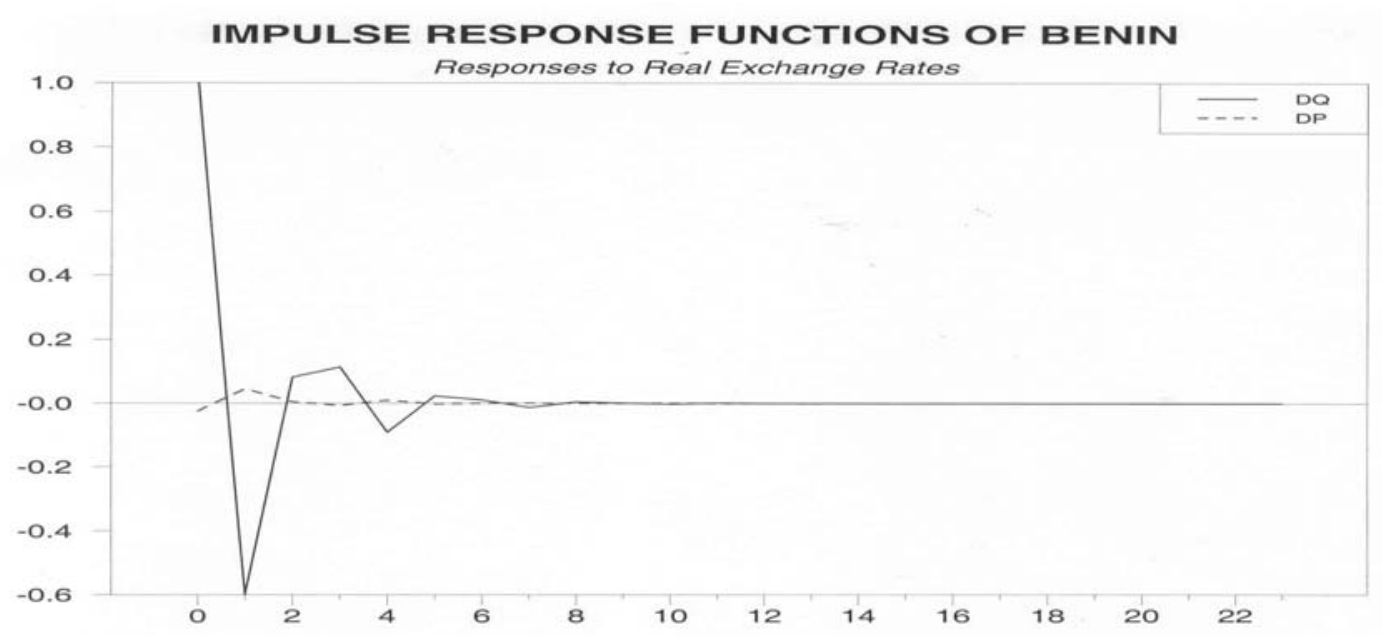

Figure 1. Impulse response functions of Benin-Responses to RER.

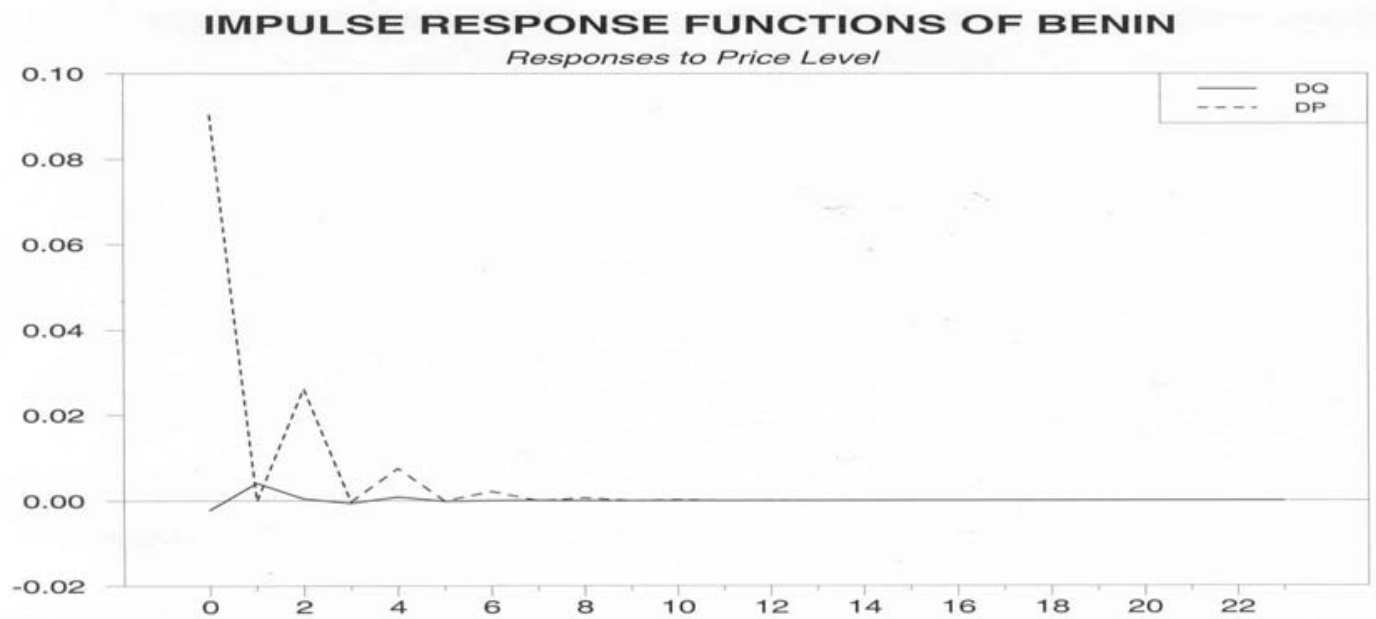

Figure 2. Impulse response functions of Benin—Responses to price level.

\section{IMPULSE RESPONSE FUNCTIONS OF BURKINA FASO}

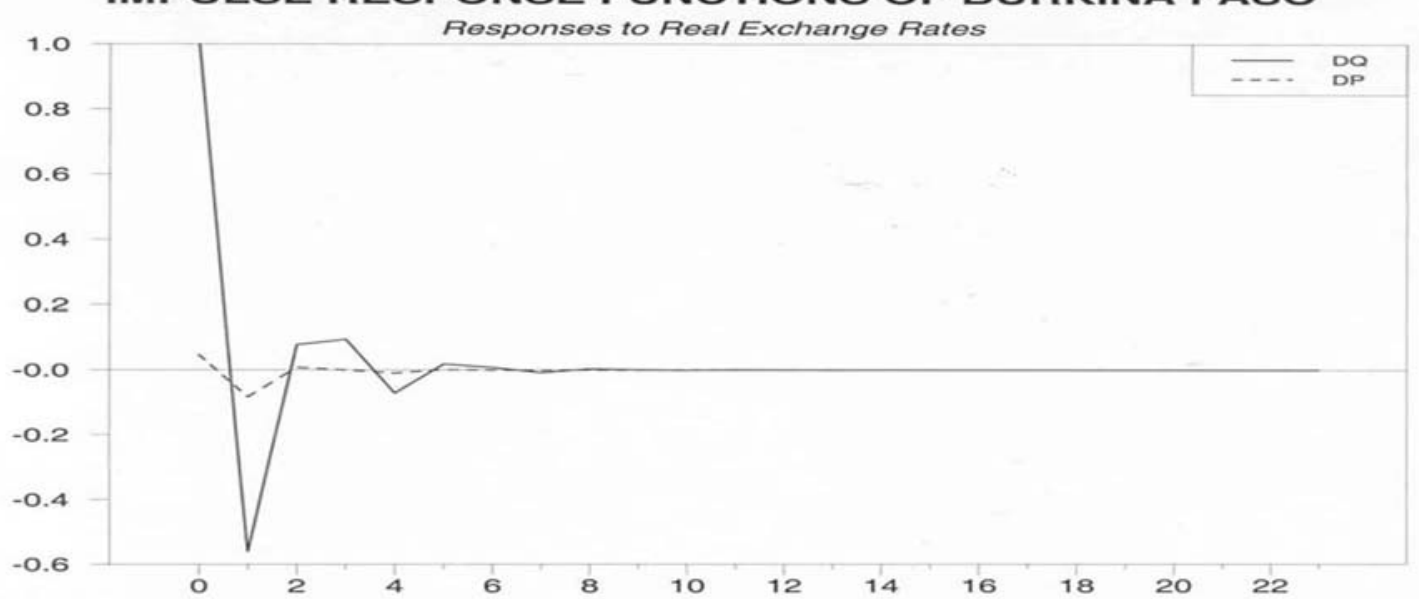

Figure 3. Impulse response functions of Burkina Faso-Responses to RER. 


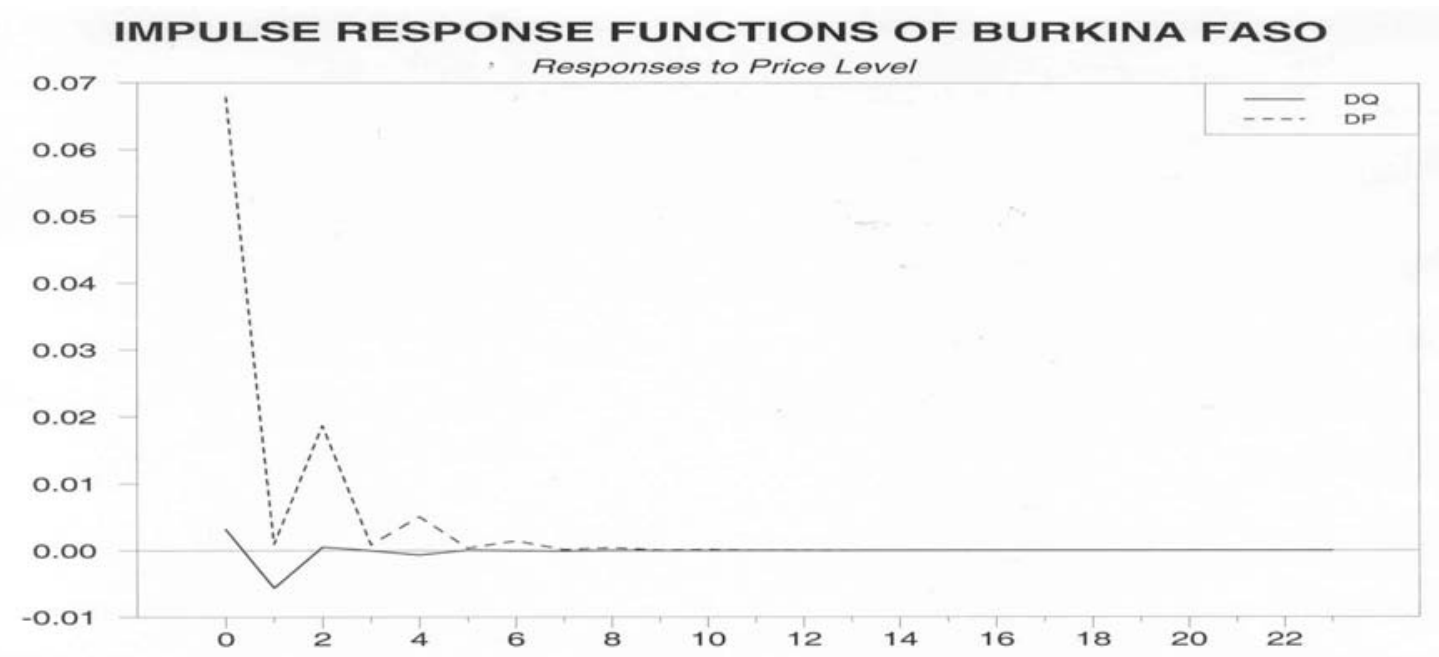

Figure 4. Impulse response functions of Burkina Faso- Responses to price level.

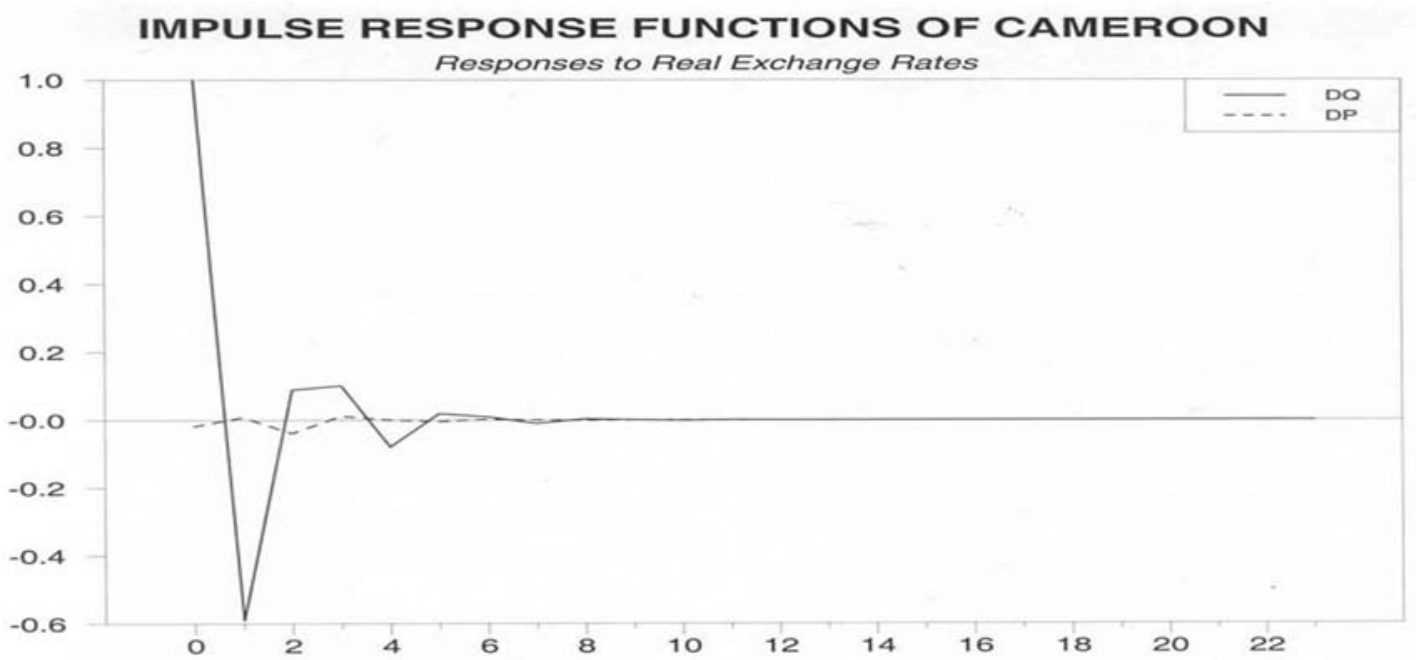

Figure 5. Impulse response functions of Cameroon-Responses to RER.

IMPULSE RESPONSE FUNCTIONS OF CAMEROON

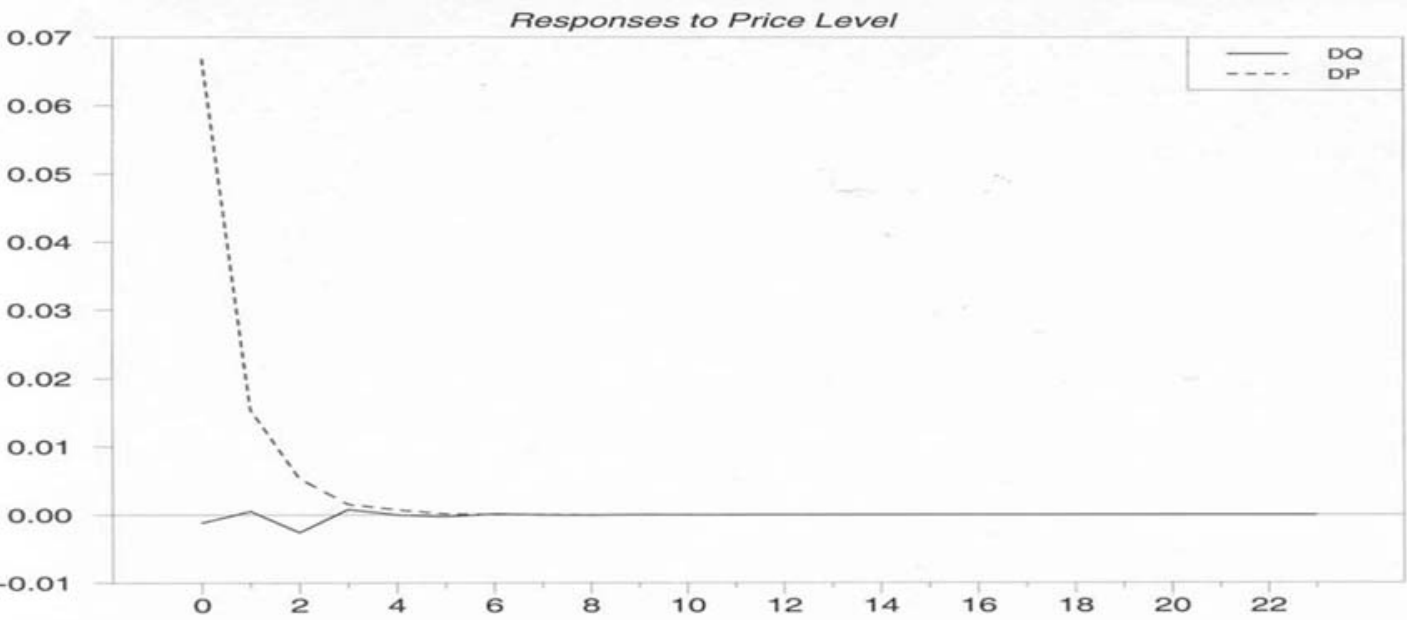

Figure 6. Impulse response functions of Cameroon-Responses to price level. 


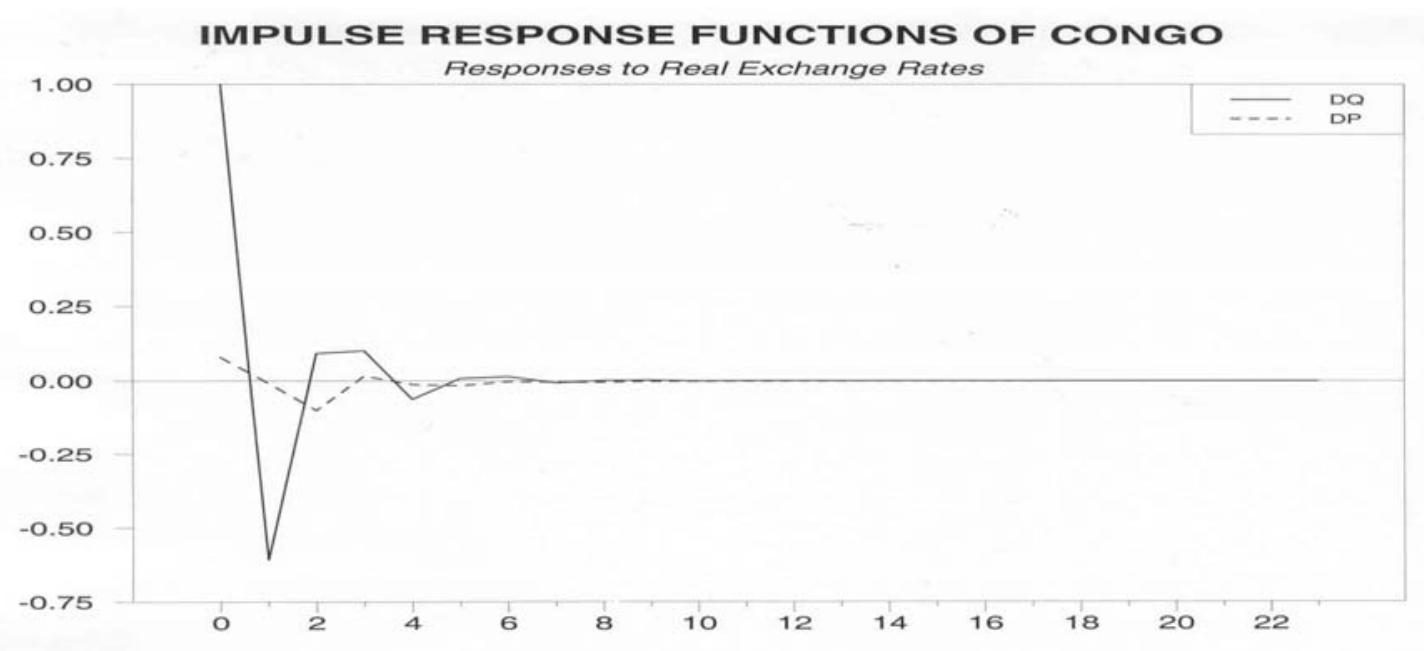

Figure 7. Impulse response functions of Congo-Responses to RER.

IMPULSE RESPONSE FUNCTIONS OF CONGO

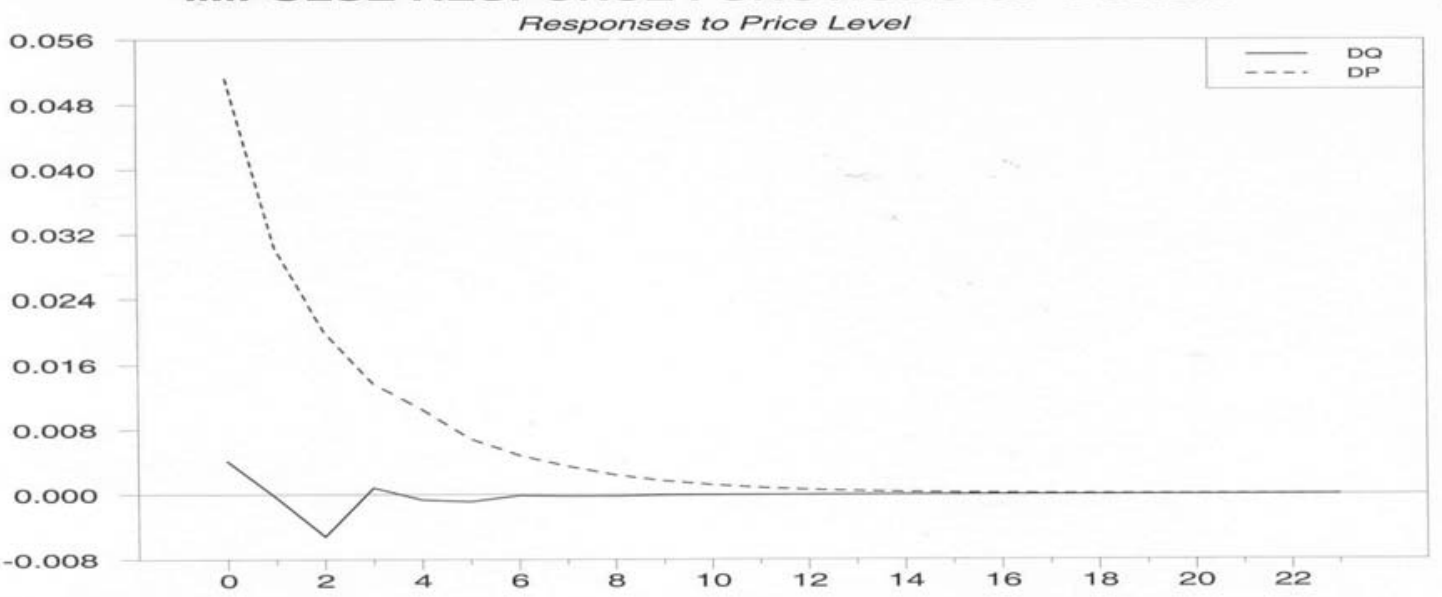

Figure 8. Impulse response functions of Congo-Responses to price level.

IMPULSE RESPONSE FUNCTIONS OF GABON

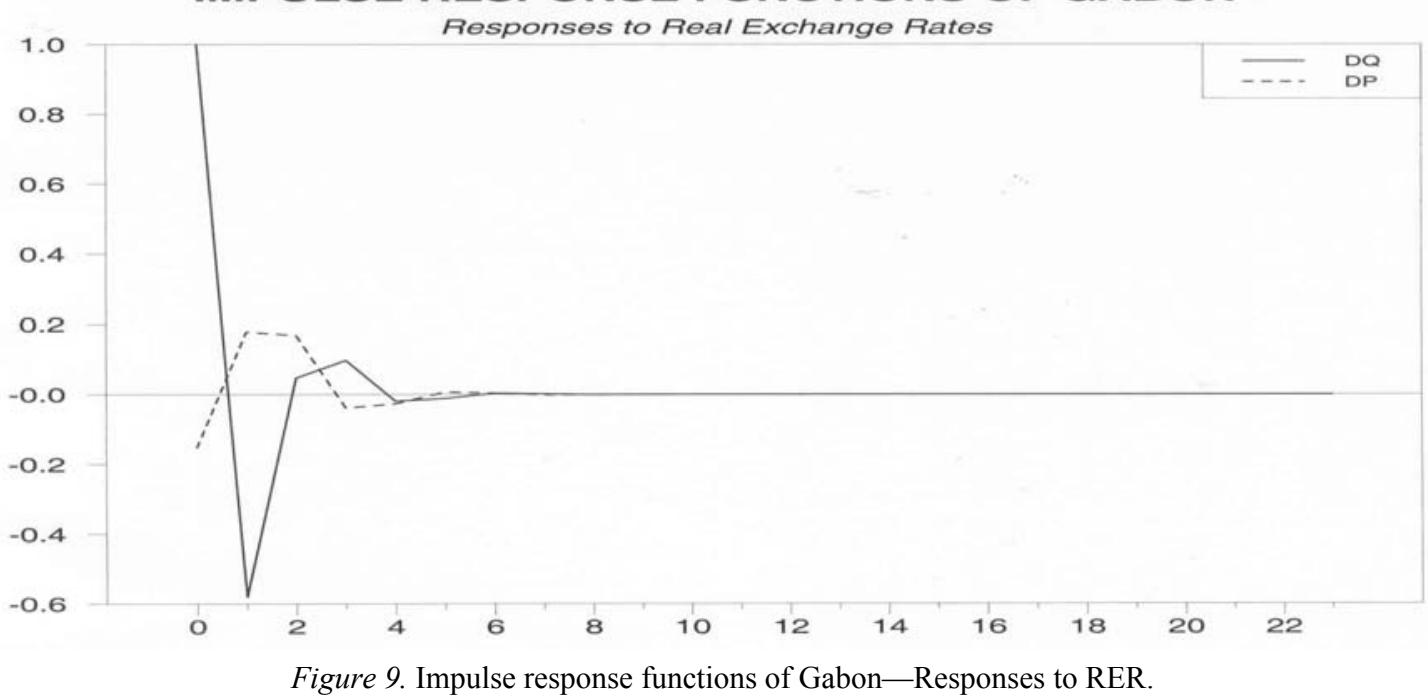




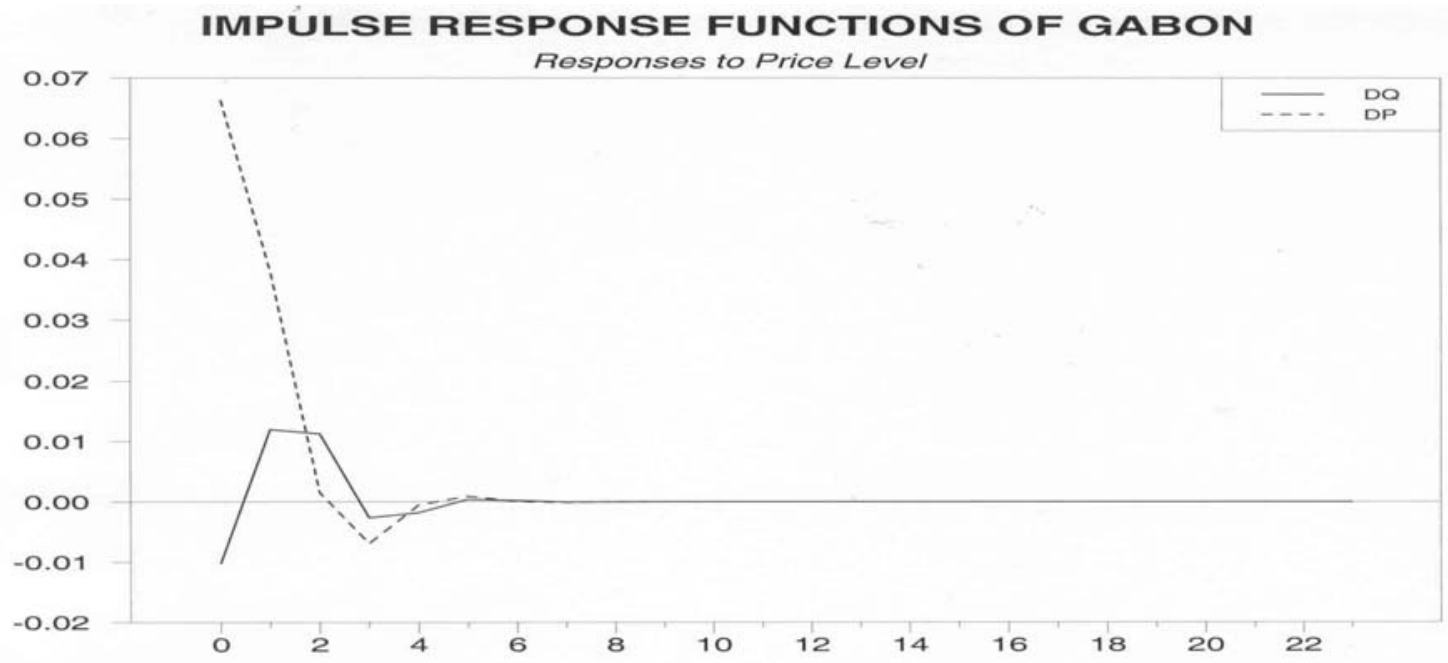

Figure 10. Impulse response functions of Gabon-Responses to price level.

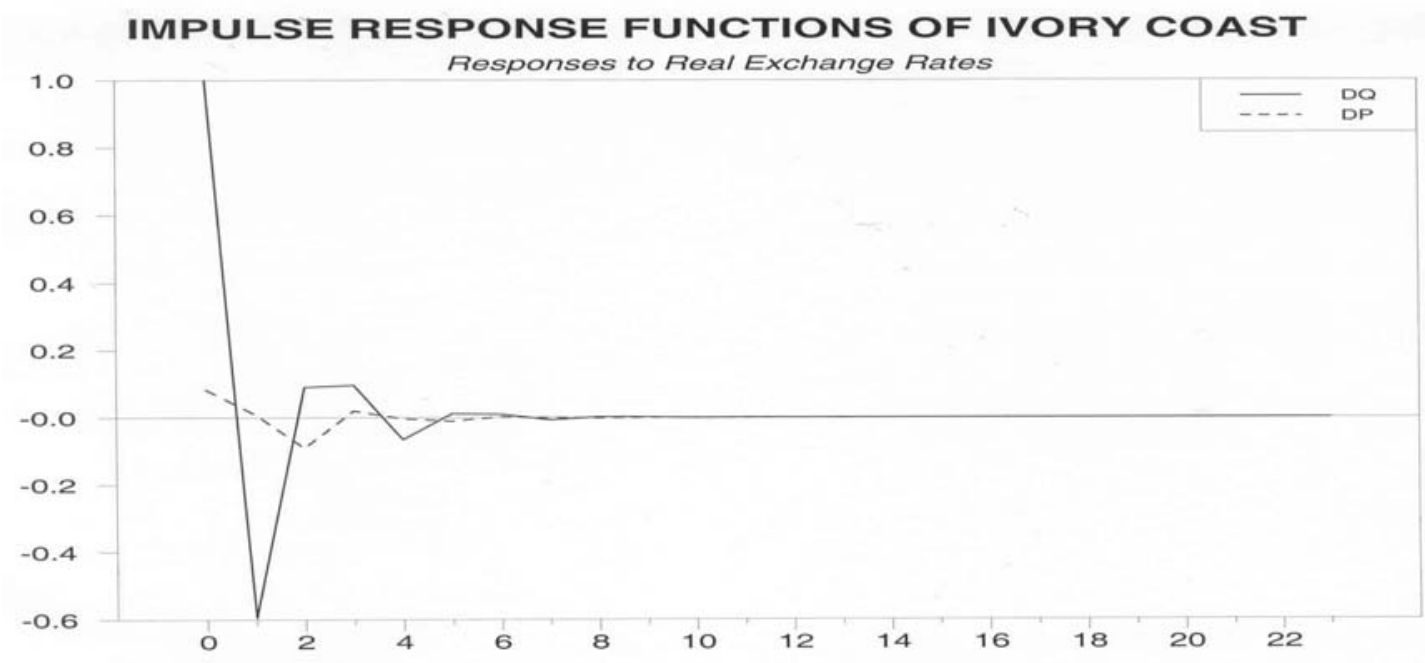

Figure 11. Impulse response functions of Ivory Coast-Responses to RER.

IMPULSE RESPONSE FUNCTIONS OF IVORY COAST

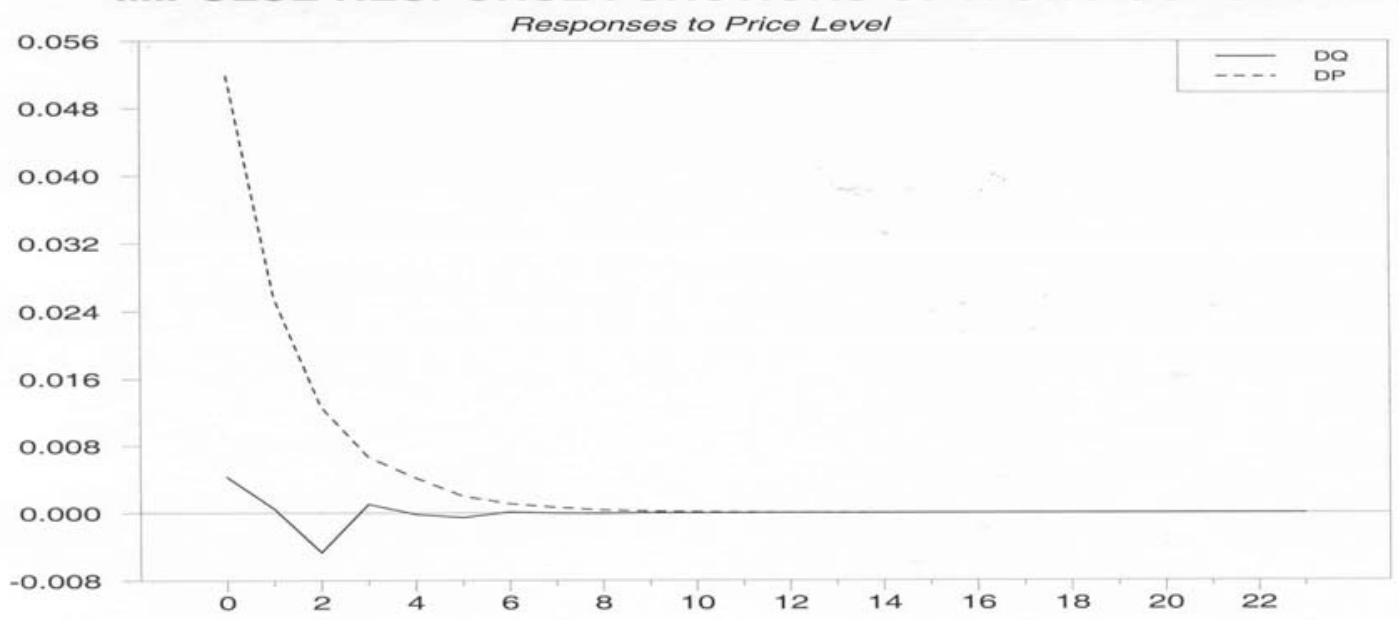

Figure 12. Impulse response functions of Ivory Coast-Responses to price level. 


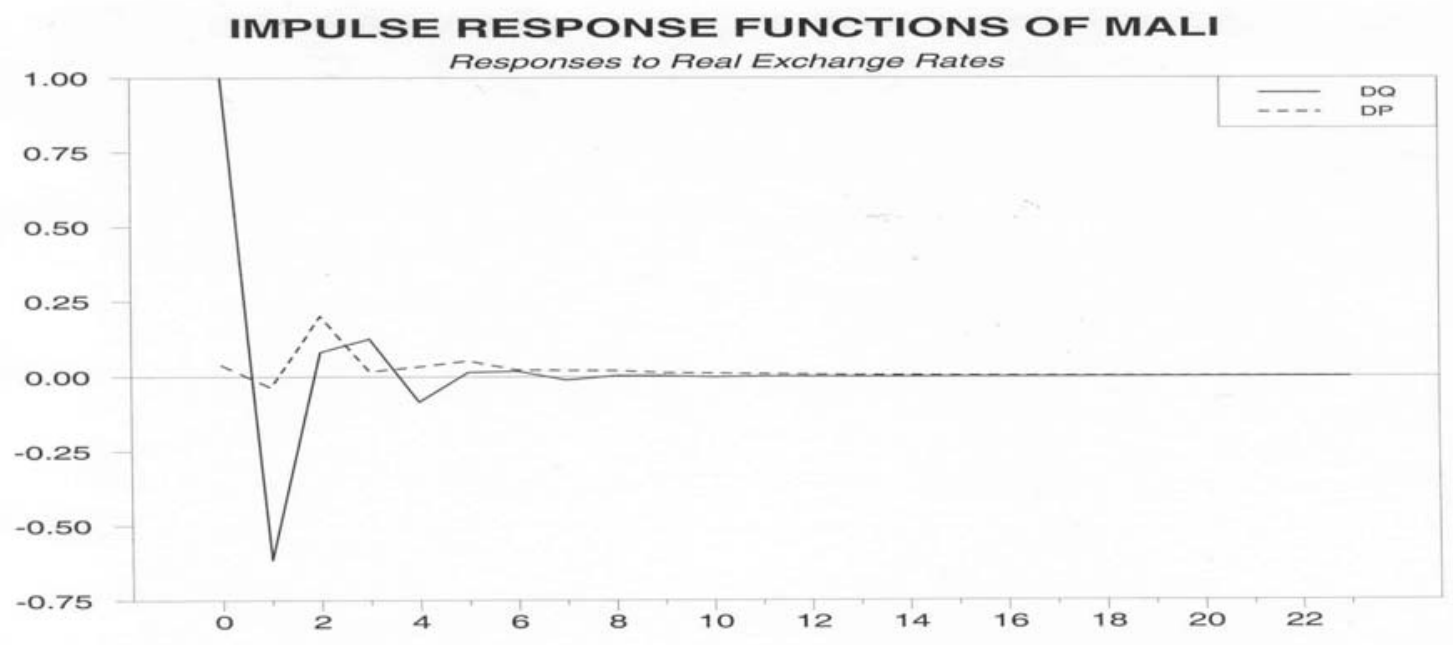

Figure 13. Impulse response functions of Mali-Responses to RER.

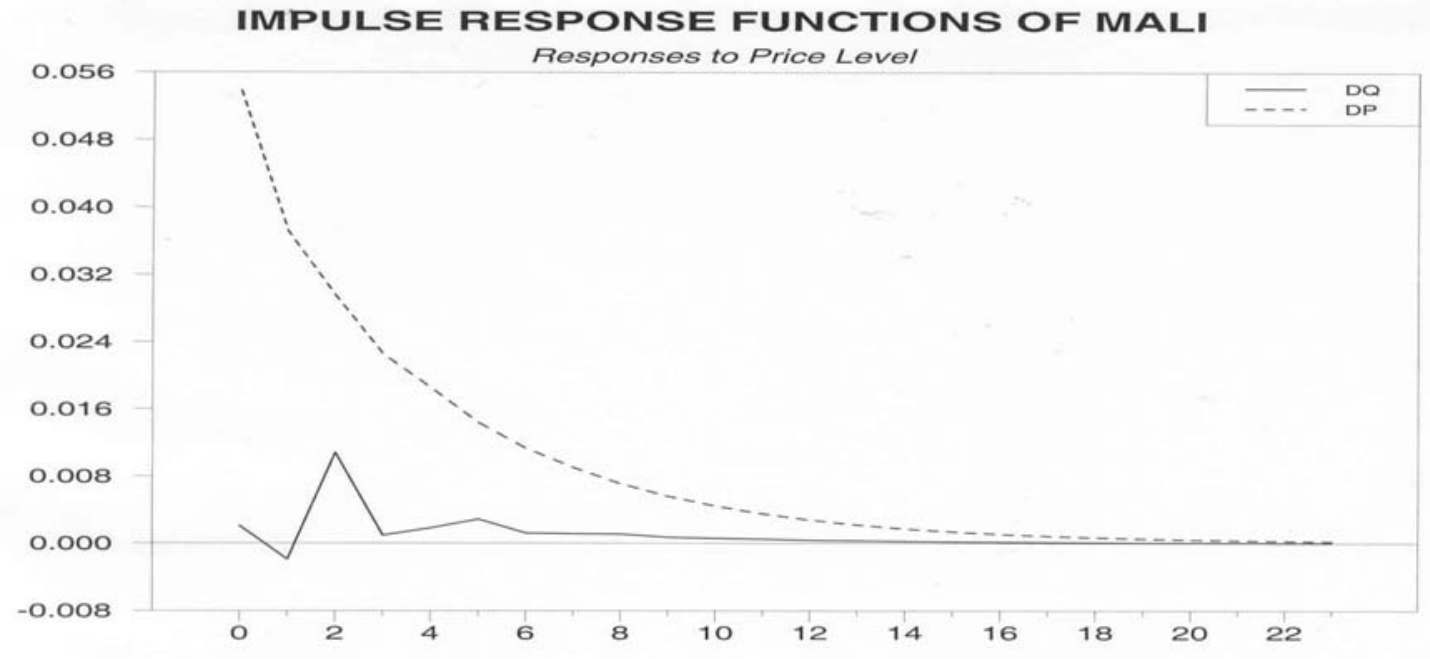

Figure 14. Impulse response functions of Mali-Responses to price level.

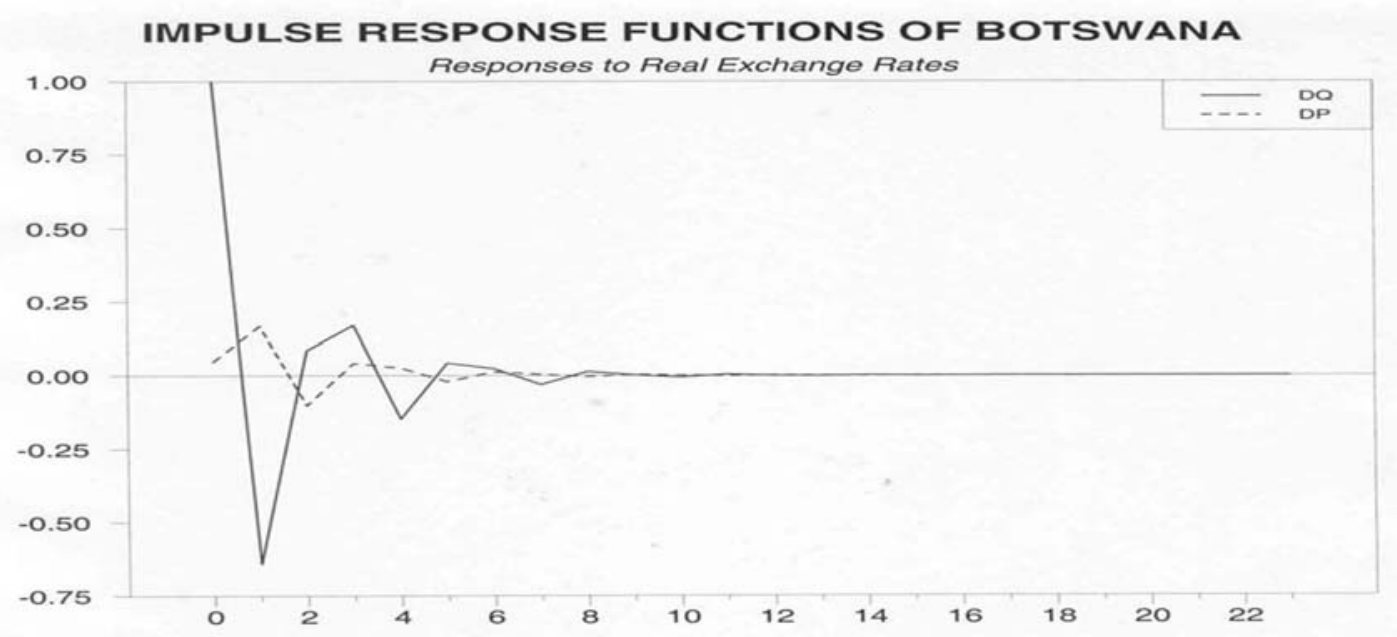

Figure 15. Impulse response functions of Botswana-Responses to RER. 


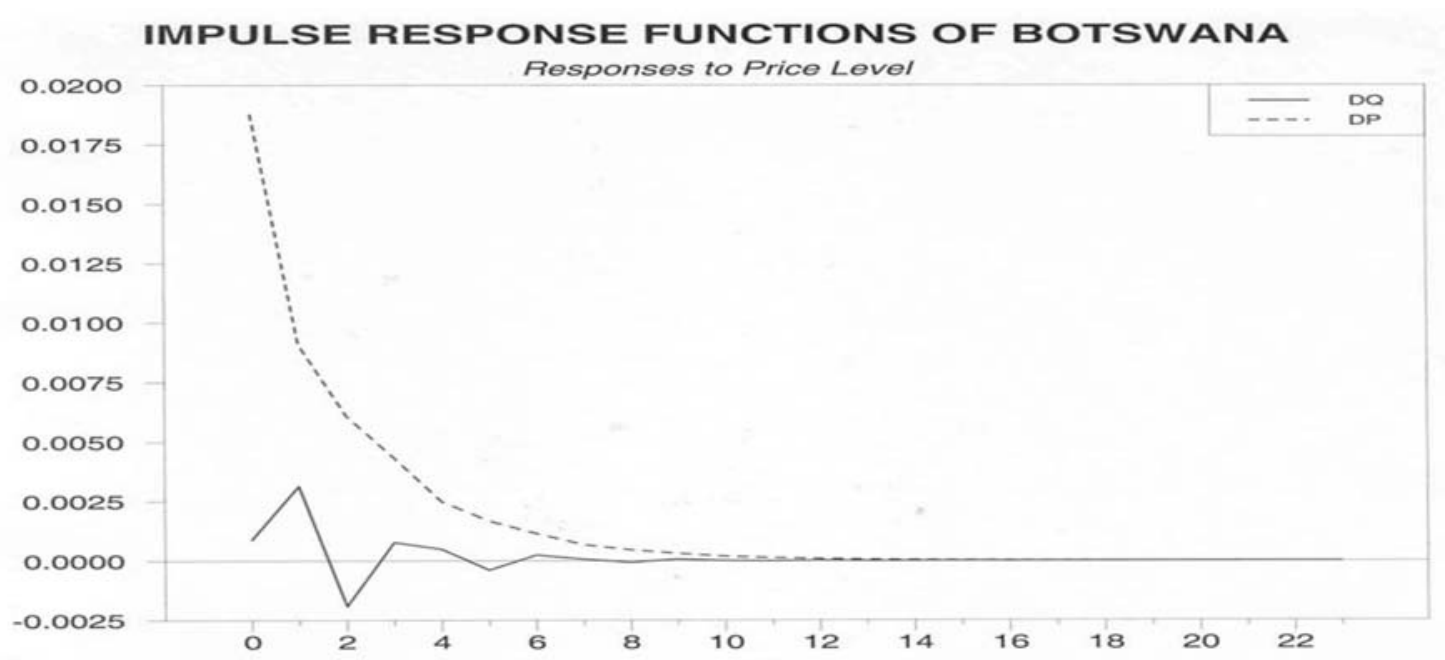

Figure 16. Impulse response functions of Botswana-Responses to price level.

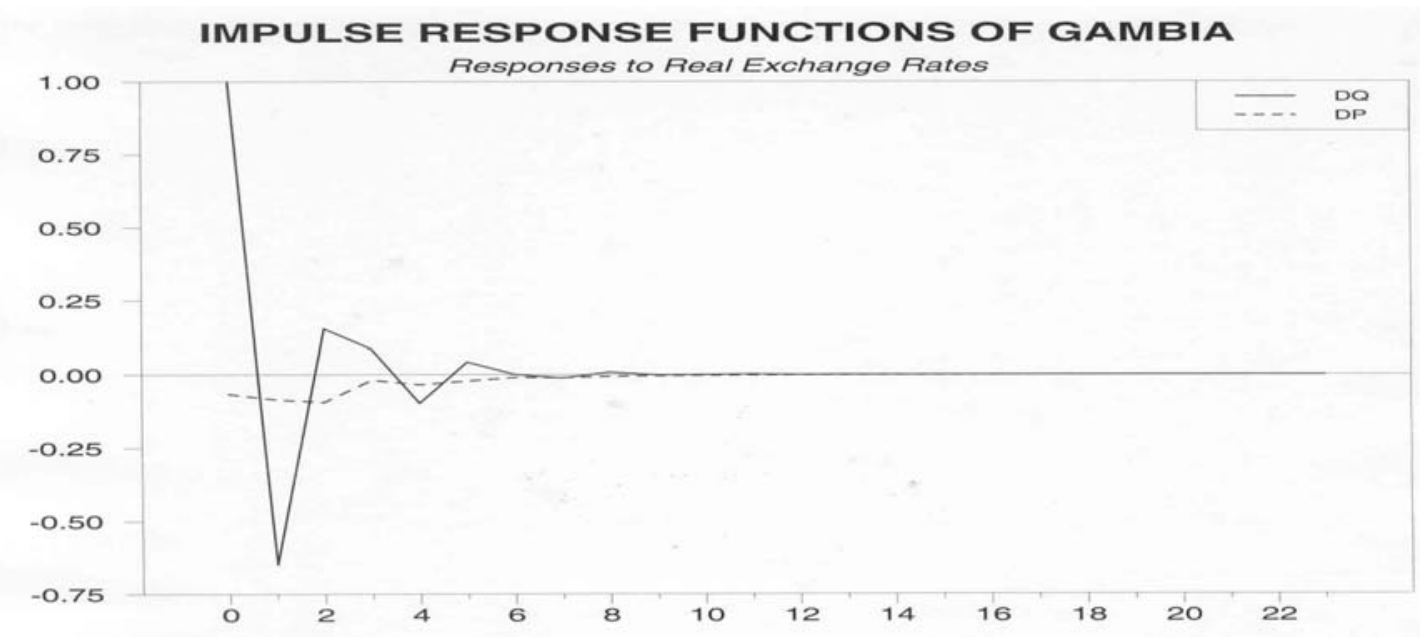

Figure 17. Impulse response functions of Gambia-Responses to RER.

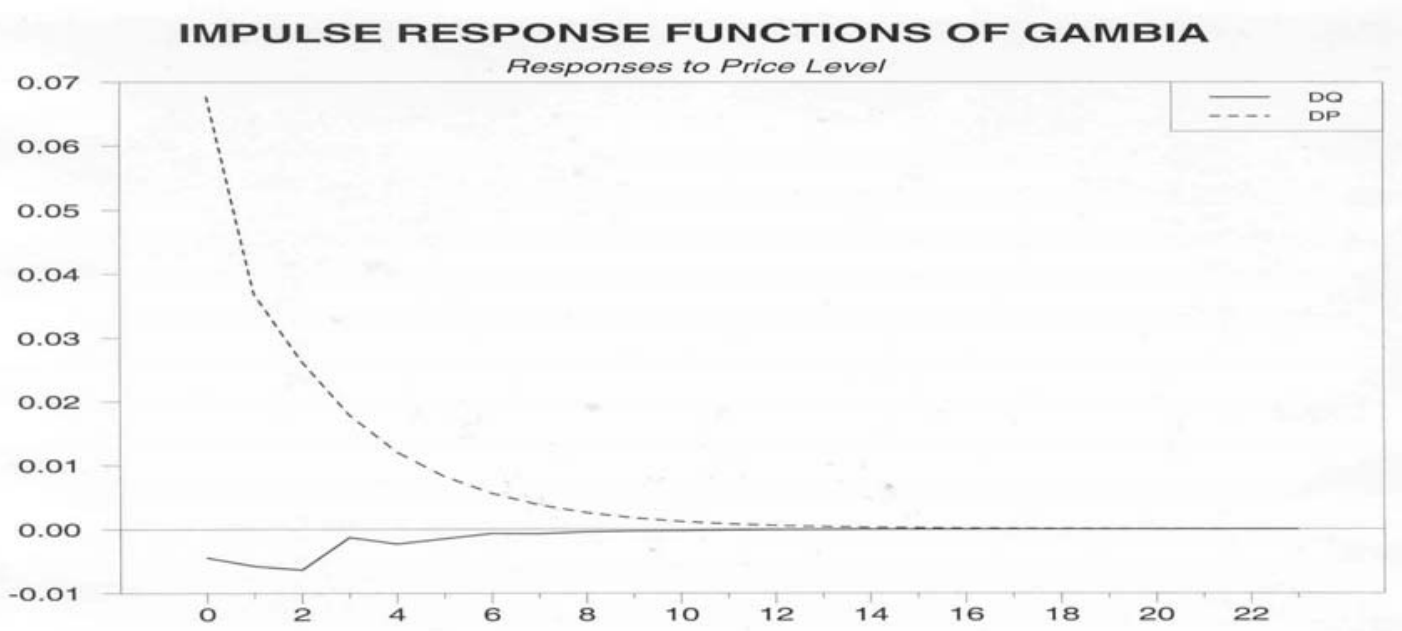

Figure 18. Impulse response functions of Gambia-Responses to price level. 


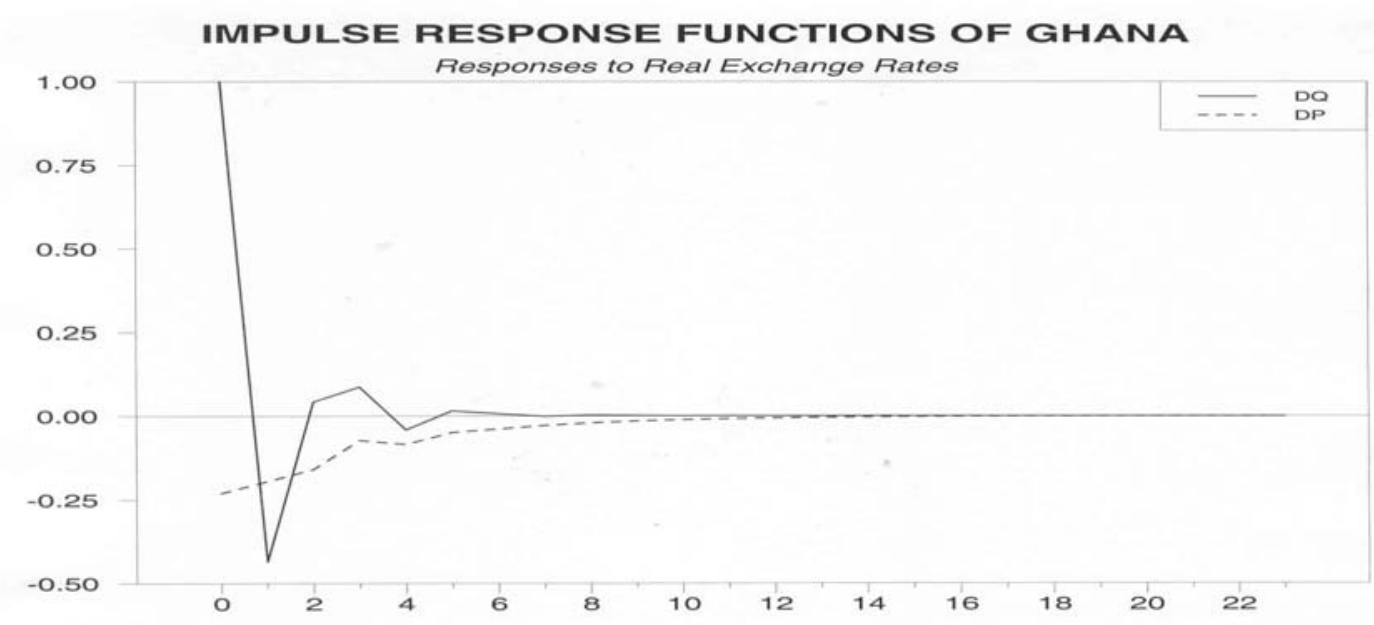

Figure 19. Impulse response functions of Ghana—Responses to RER.

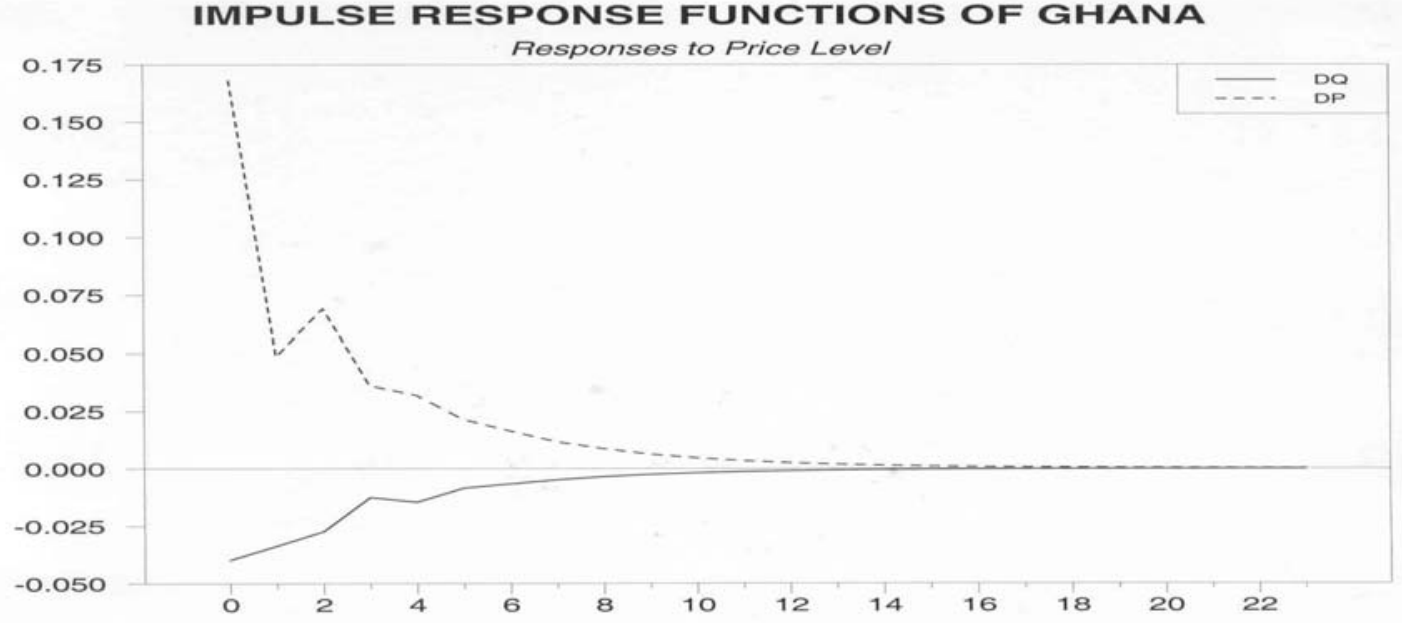

Figure 20. Impulse response functions of Ghana-Responses to price level.

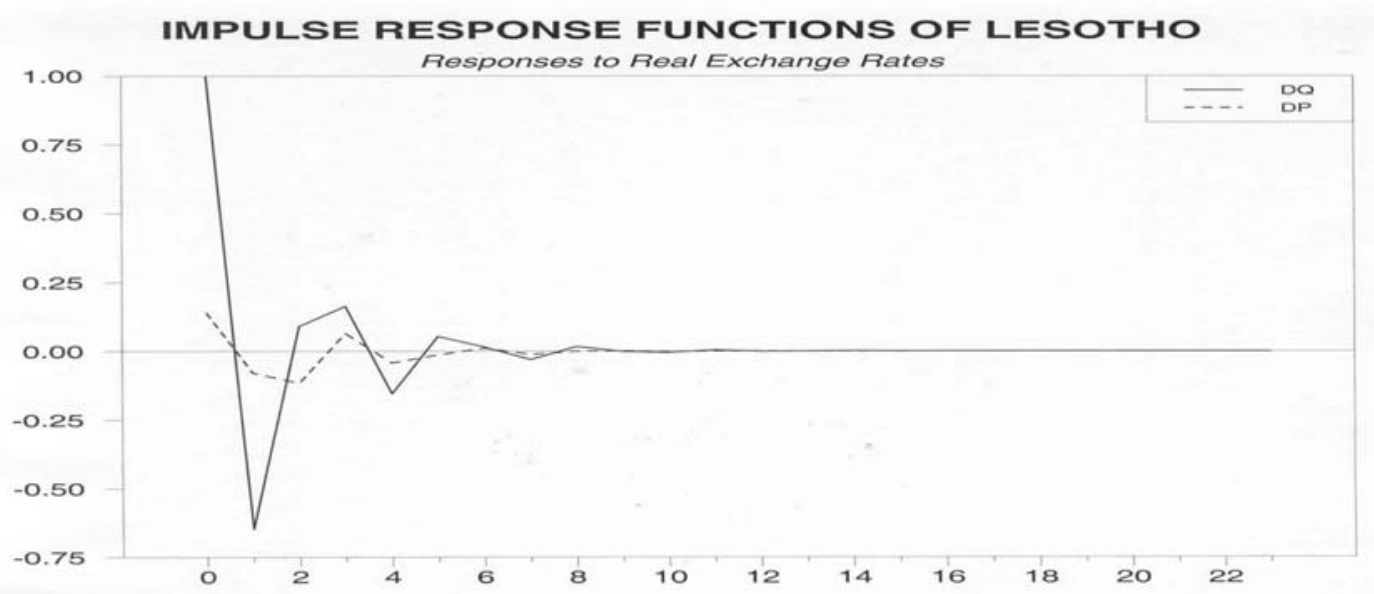

Figure 21. Impulse response functions of Lesotho-Responses to RER. 
IMPULSE RESPONSE FUNCTIONS OF LESOTHO

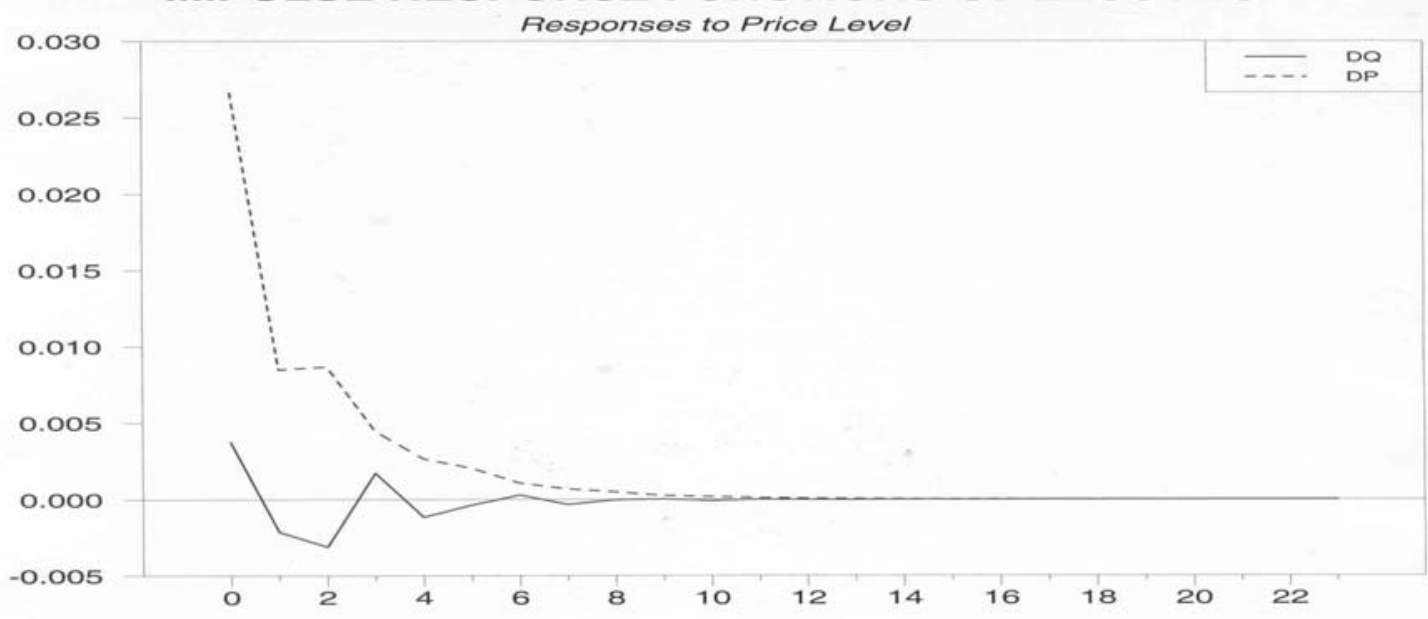

Figure 22. Impulse response functions of Lesotho--Responses to price level.

IMPULSE RESPONSE FUNCTIONS OF MALAWI

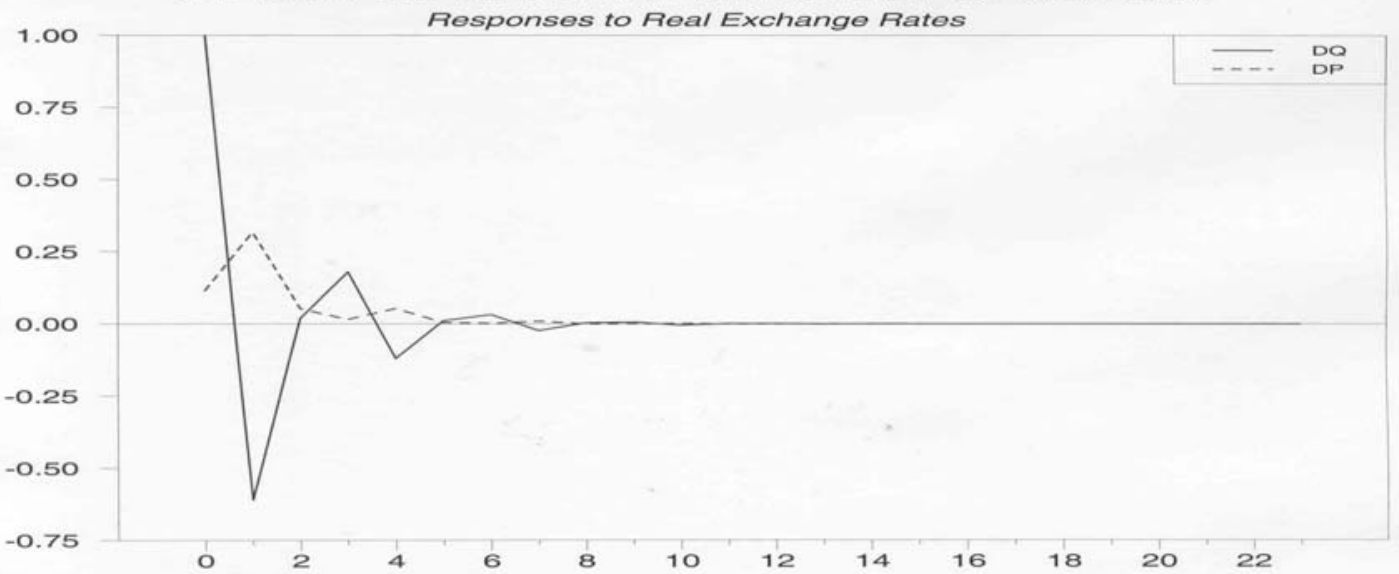

Figure 23. Impulse response functions of Malawi-Responses to RER.

IMPULSE RESPONSE FUNCTIONS OF MALAWI

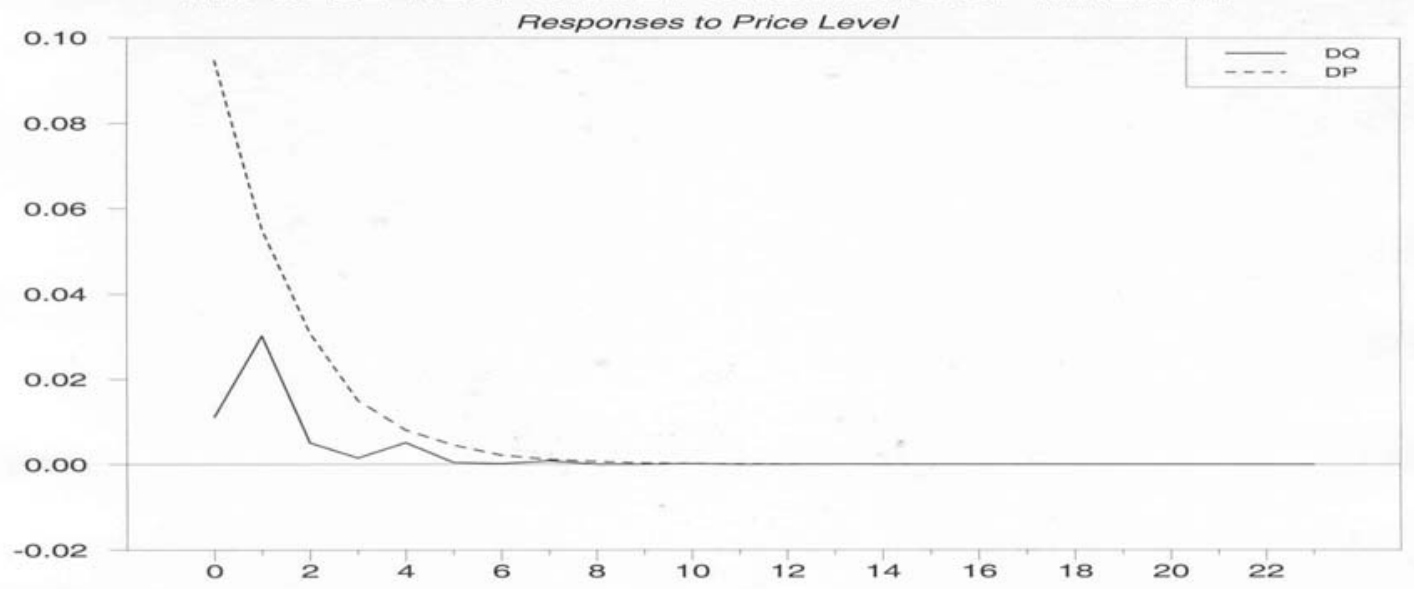

Figure 24. Impulse response functions of Malawi-Responses to price level. 


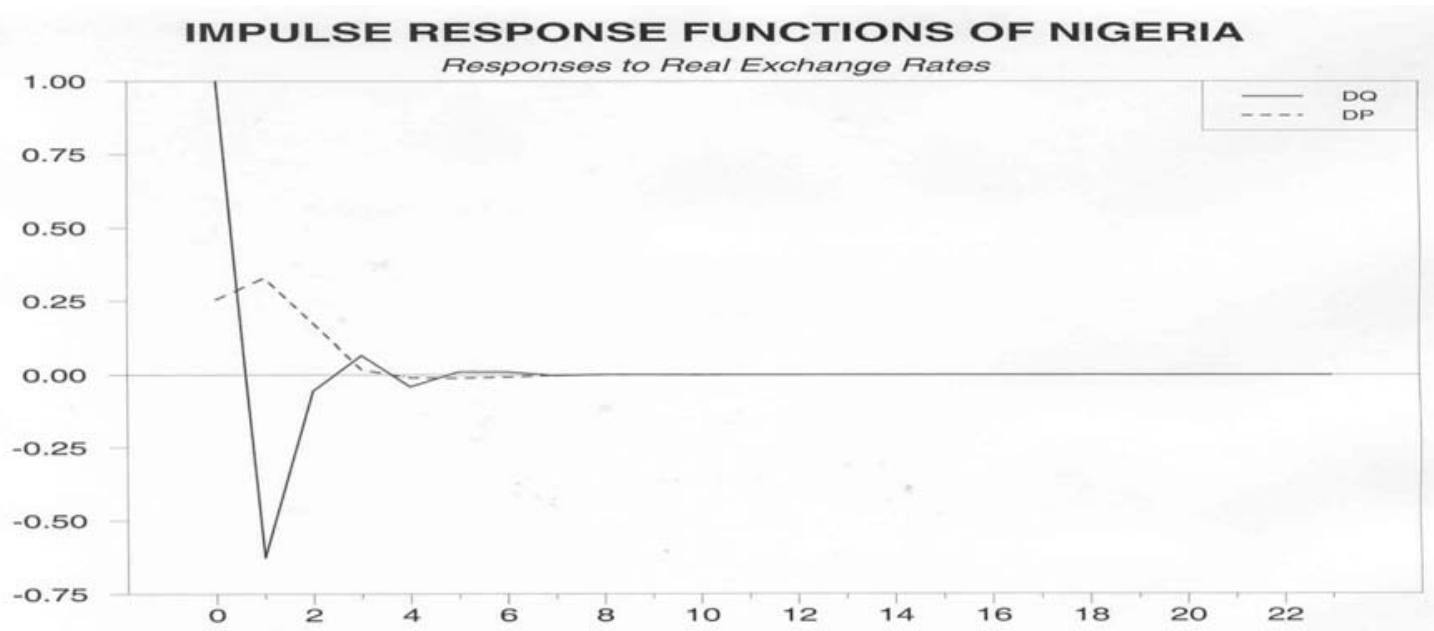

Figure 25. Impulse response functions of Nigeria-Responses to RER.

\section{IMPULSE RESPONSE FUNCTIONS OF NIGERIA}

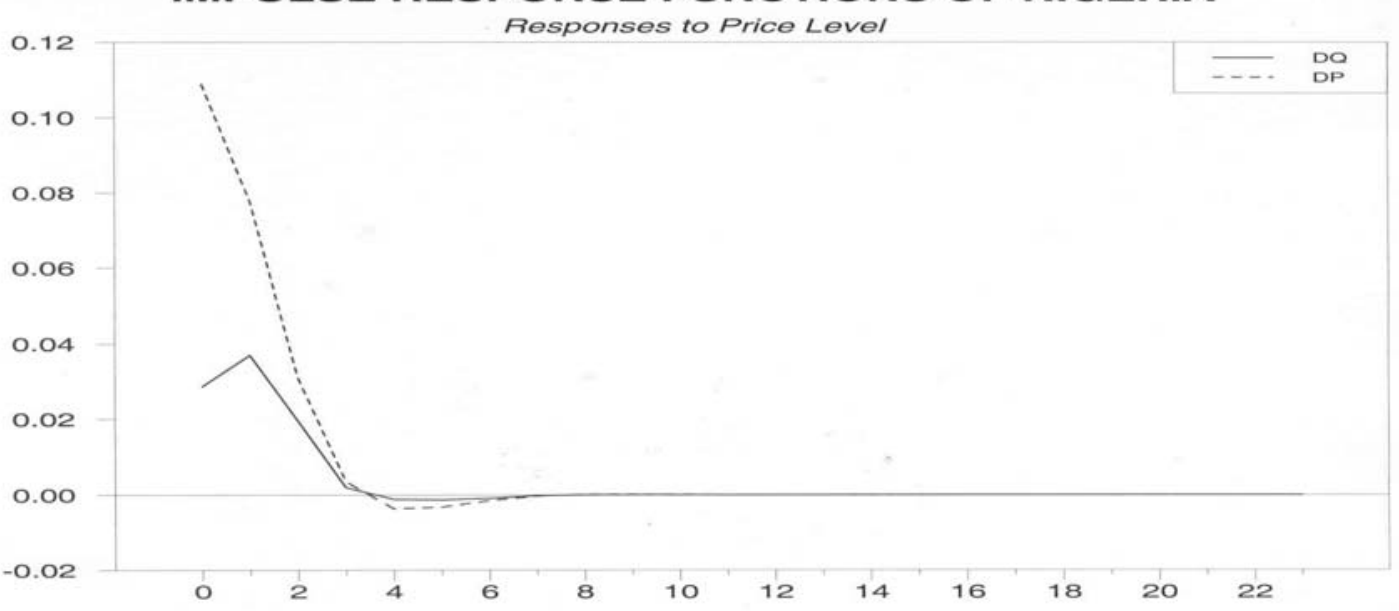

Figure 26. Impulse response functions of Nigeria-Responses to price level.

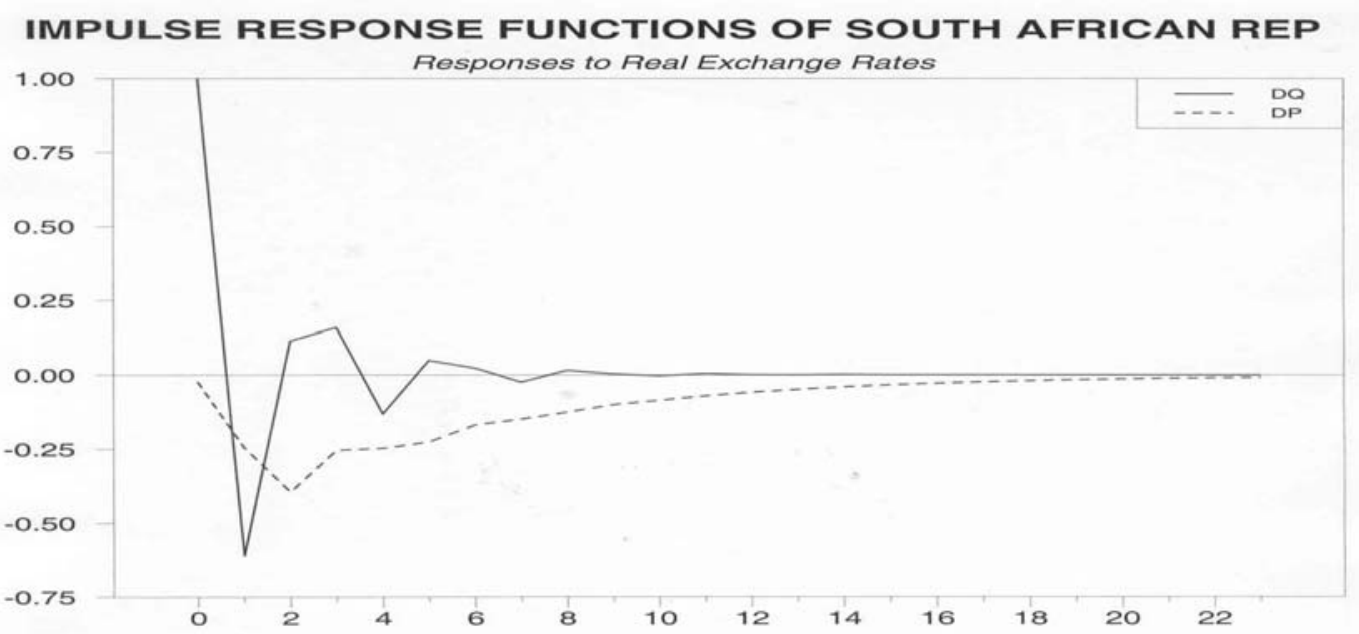

Figure 27. Impulse response functions of South African Republic-Responses to RER. 


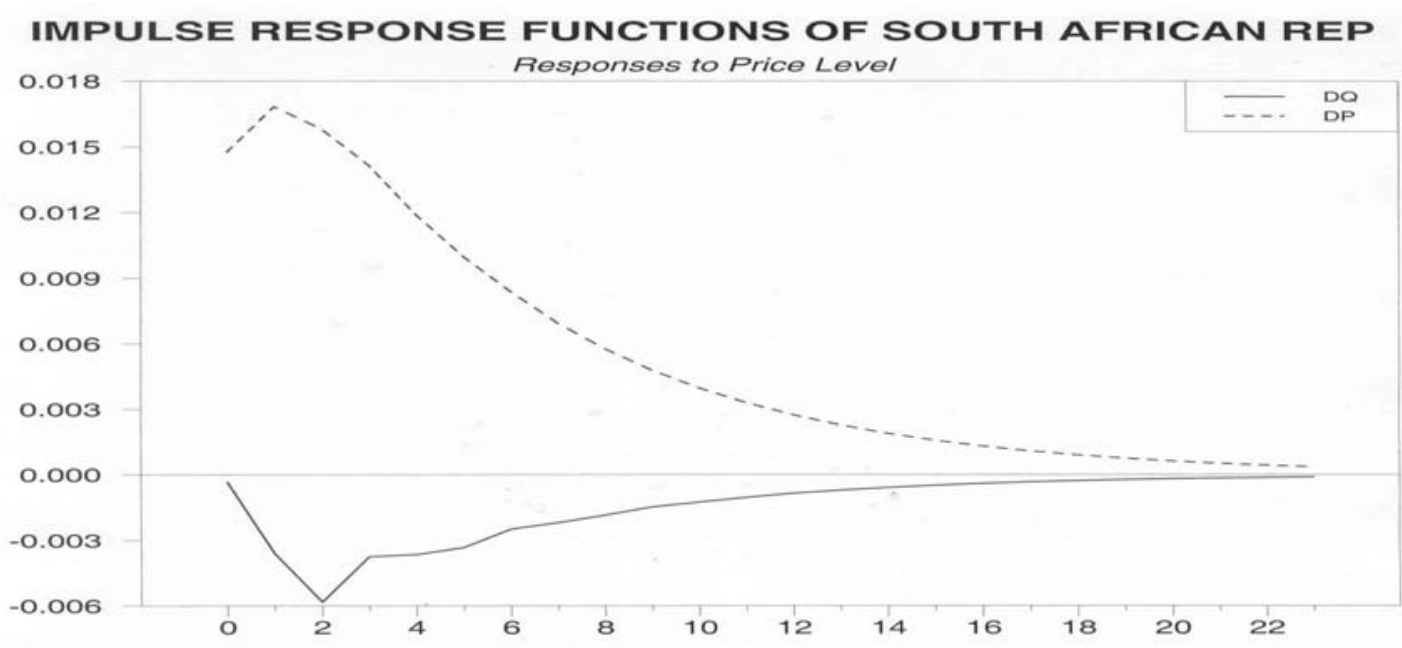

Figure 28. Impulse response functions of South African Republic—Responses to price level.

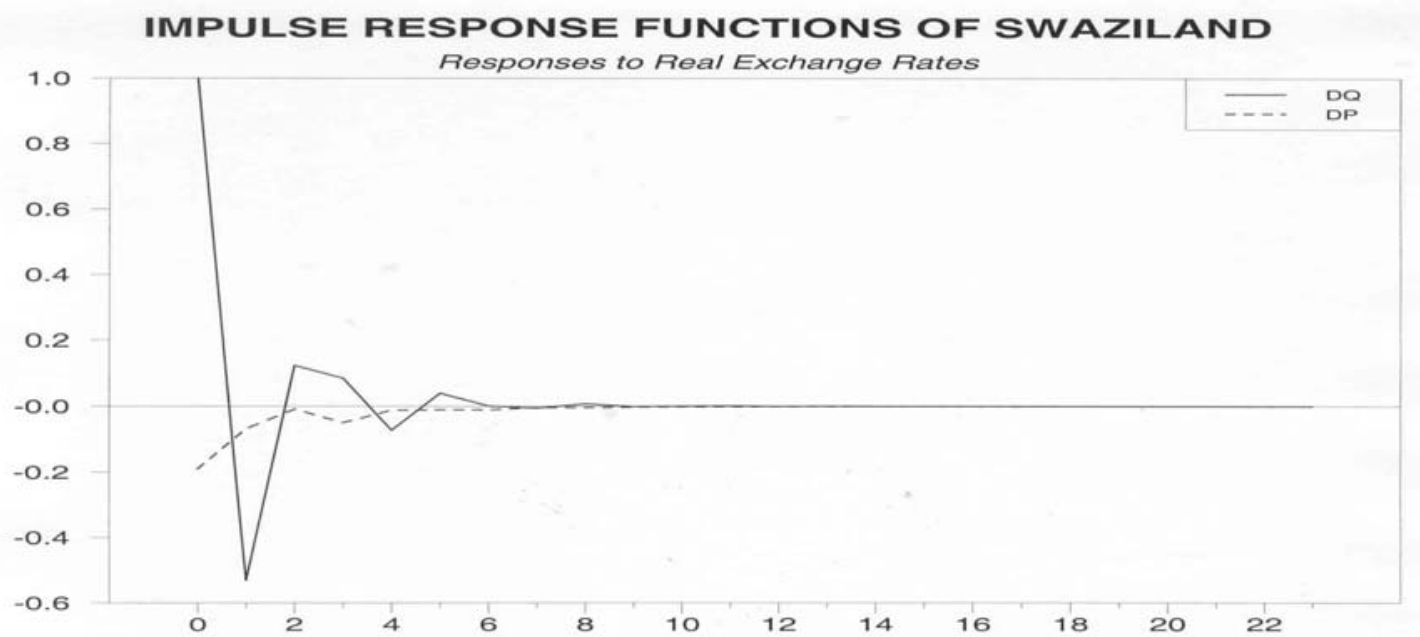

Figure 29. Impulse response functions of Swaziland—Responses to RER.

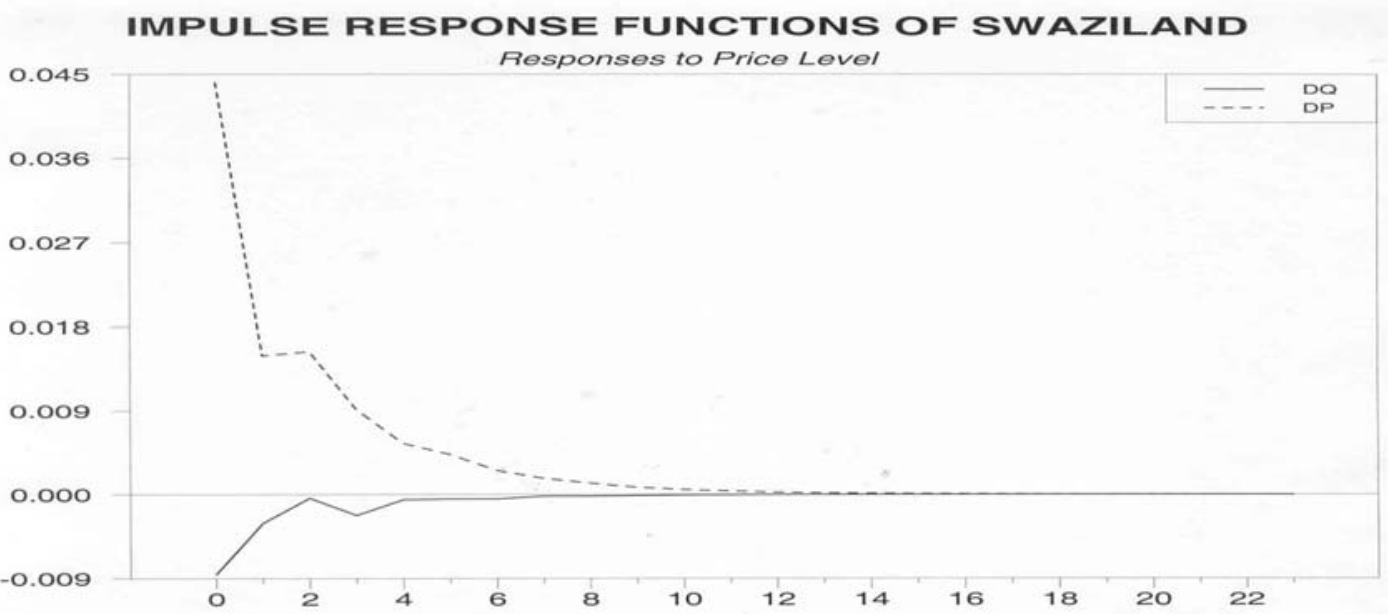

Figure 30. Impulse response functions of Swaziland-Responses to price level. 
Overall, only real shocks seem to matter in explaining real exchange rate fluctuations in both the CFA and non-CFA countries, and nominal shocks play the major role in the variability of prices. Hoffmaister and Roldós (1996) find similar results about South Korea and Brazil.

The results of the VD of real exchange rates and prices are given in Table 3. The main source of real exchange rate fluctuations in the CFA countries is real shocks in the short and long run. Real disturbances such as technological innovations, productivity improvements, structural reforms or economies of scale explain over 80 percent of the RER variability in the short run (one year) and long run (eight years) in the CFA countries except in Congo where it is only 73 percent. Nominal shocks have a smaller impact on the variation of the RER in the CFA countries even in the short run. They account for less than 7 percent in the short run except for Côte d'Ivoire, Mali, and Congo where they are 8 percent, 11 percent, and 20 percent, respectively.

Table 3

Variances Decompositions for CFA and Non-CFA Countries

\begin{tabular}{|c|c|c|c|c|c|c|c|c|c|c|c|}
\hline \multirow{2}{*}{$\begin{array}{l}\text { CFA } \\
\text { countries }\end{array}$} & \multirow{2}{*}{ Year } & \multicolumn{2}{|c|}{ RER } & \multicolumn{2}{|c|}{ Prices } & \multicolumn{2}{|c|}{ RER } & \multicolumn{2}{|c|}{ Prices } & \multirow{2}{*}{ Year } & \multirow{2}{*}{$\begin{array}{l}\text { Non-CFA } \\
\text { countries }\end{array}$} \\
\hline & & $\varepsilon_{t}^{r}$ & $\varepsilon_{t}^{n}$ & $\varepsilon_{t}^{r}$ & $\varepsilon_{t}^{n}$ & $\varepsilon_{t}^{r}$ & $\varepsilon_{t}^{n}$ & $\varepsilon_{t}^{r}$ & $\varepsilon_{t}^{n}$ & & \\
\hline \multirow[t]{3}{*}{ Benin } & 1 & 99.06 & 0.94 & 0.93 & 99.07 & 99.99 & 0.01 & 0.15 & 99.85 & 1 & Botswana \\
\hline & 4 & 98.74 & 1.26 & 6.90 & 93.10 & 98.61 & 1.40 & 2.82 & 97.18 & 4 & \\
\hline & 8 & 98.69 & 1.31 & 14.41 & 85.59 & 98.59 & 1.41 & 2.84 & 97.16 & 8 & \\
\hline \multirow{3}{*}{$\begin{array}{l}\text { Burkina } \\
\text { Faso }\end{array}$} & 1 & 97.96 & 2.04 & 0.93 & 99.07 & 99.99 & 0.01 & 0.04 & 99.96 & 1 & Burundi \\
\hline & 4 & 97.20 & 2.80 & 1.91 & 98.40 & 94.85 & 5.16 & 1.84 & 98.16 & 4 & \\
\hline & 8 & 97.15 & 2.85 & 1.64 & 98.36 & 94.73 & 5.27 & 1.88 & 98.12 & 8 & \\
\hline \multirow[t]{3}{*}{ Cameroon } & 1 & 98.48 & 1.52 & 1.98 & 98.02 & 97.21 & 2.79 & 9.03 & 90.97 & 1 & Ethiopia \\
\hline & 4 & 97.86 & 2.14 & 2.14 & 97.87 & 95.80 & 4.20 & 19.94 & 80.06 & 4 & \\
\hline & 8 & 97.86 & 2.15 & 2.14 & 97.86 & 95.81 & 4.20 & 19.94 & 80.06 & 8 & \\
\hline \multirow{3}{*}{$\begin{array}{l}\text { Central } \\
\text { African } \\
\text { Republic }\end{array}$} & 1 & 99.07 & 0.93 & 316 & 96.84 & 97.51 & 2.41 & 4.96 & 95.04 & 1 & Gambia \\
\hline & 4 & 98.10 & 1.90 & 5.70 & 94.30 & 96.27 & 3.73 & 6.90 & 93.10 & 4 & \\
\hline & 8 & 98.09 & 1.91 & 5.72 & 94.28 & 96.25 & 3.75 & 7.04 & 92.96 & 8 & \\
\hline \multirow[t]{3}{*}{ Chad } & 1 & 93.27 & 6.73 & 5.54 & 94.46 & 90.08 & 9.92 & 27.60 & 72.40 & 1 & Ghana \\
\hline & 4 & 89.16 & 10.84 & 6.73 & 93.27 & 84.24 & $\begin{array}{c}15.7 \\
6\end{array}$ & 32.98 & 67.02 & 4 & \\
\hline & 8 & 88.95 & 11.05 & 6.78 & 93.22 & 84.22 & $\begin{array}{c}15.7 \\
8\end{array}$ & 33.58 & 66.42 & 8 & \\
\hline \multirow[t]{3}{*}{ Congo } & 1 & 72.94 & 27.06 & 20.30 & 79.70 & 95.70 & 4.30 & 0.52 & 99.48 & 1 & Kenya \\
\hline & 4 & 73.16 & 26.84 & 25.29 & 74.71 & 95.77 & 4.23 & 1.58 & 98.42 & 4 & \\
\hline & 8 & 72.98 & 27.02 & 25.67 & 74.33 & 95.74 & 4.26 & 1.61 & 98.39 & 8 & \\
\hline \multirow{3}{*}{$\begin{array}{l}\text { Cote } \\
\text { D'Ivoire }\end{array}$} & 1 & 86.77 & 13.23 & 8.16 & 91.84 & 98.44 & 1.56 & 6.85 & 93.15 & 1 & Lesotho \\
\hline & 4 & 85.13 & 14.88 & 10.65 & 89.35 & 97.31 & 2.69 & 6.59 & 93.41 & 4 & \\
\hline & 8 & 85.08 & 14.93 & 10.70 & 89.30 & 97.25 & 2.75 & 6.59 & 93.41 & 8 & \\
\hline \multirow[t]{3}{*}{ Gabon } & 1 & 99.84 & 0.52 & 4.98 & 95.02 & 95.25 & 4.76 & 11.77 & 88.23 & 1 & Madagascar \\
\hline & 4 & 88.01 & 11.99 & 6.96 & 93.04 & 94.46 & 5.54 & 11.60 & 88.40 & 4 & \\
\hline & 8 & 87.89 & 12.11 & 7.01 & 92.99 & 94.48 & 5.52 & 11.65 & 88.36 & 8 & \\
\hline \multirow[t]{3}{*}{ Mali } & 1 & 91.12 & 8.88 & 11.20 & 88.80 & 98.33 & 1.67 & 0.02 & 99.98 & 1 & Malawi \\
\hline & 4 & 91.37 & 8.63 & 14.42 & 85.59 & 98.13 & 1.87 & 3.67 & 96.33 & 4 & \\
\hline & 8 & 91.28 & 8.72 & 14.80 & 85.21 & 98.13 & 1.87 & 3.76 & 96.25 & 8 & \\
\hline
\end{tabular}


(Table 3 continued)

\begin{tabular}{|c|c|c|c|c|c|c|c|c|c|c|c|}
\hline \multirow{2}{*}{$\begin{array}{l}\text { CFA } \\
\text { countries }\end{array}$} & \multirow{2}{*}{ Year } & \multicolumn{2}{|c|}{ RER } & \multicolumn{2}{|c|}{ Prices } & \multicolumn{2}{|c|}{ RER } & \multicolumn{2}{|c|}{ Prices } & \multirow{2}{*}{ Year } & \multirow{2}{*}{$\begin{array}{l}\text { Non-CFA } \\
\text { countries }\end{array}$} \\
\hline & & $\varepsilon_{t}^{r}$ & $\varepsilon_{t}^{n}$ & $\varepsilon_{t}^{r}$ & $\varepsilon_{t}^{n}$ & $\varepsilon_{t}^{r}$ & $\varepsilon_{t}^{n}$ & $\varepsilon_{t}^{r}$ & $\varepsilon_{t}^{n}$ & & \\
\hline \multirow[t]{3}{*}{ Niger } & 1 & 99.77 & 0.23 & 1.22 & 98.78 & 99.58 & 0.43 & 3.78 & 96.22 & 1 & Mauritius \\
\hline & 4 & 99.70 & 0.30 & 1.63 & 98.37 & 96.90 & 3.10 & 3.75 & 96.26 & 4 & \\
\hline & 8 & 99.70 & 0.30 & 1.64 & 98.36 & 96.89 & 3.11 & 3.74 & 96.26 & 8 & \\
\hline \multirow[t]{3}{*}{ Senegal } & 1 & 99.94 & 0.06 & 0.15 & 99.85 & 29.80 & 70.20 & 45.07 & 54.93 & 1 & Nigeria \\
\hline & 4 & 99.77 & 0.23 & 1.00 & 99.01 & 19.24 & 80.76 & 37.18 & 62.82 & 4 & \\
\hline & 8 & 99.77 & 0.24 & 1.04 & 98.86 & 19.25 & 80.75 & 37.18 & 62.83 & 8 & \\
\hline \multirow[t]{21}{*}{ Togo } & 1 & 98.70 & 1.30 & 6.69 & 93.31 & 93.29 & 6.71 & 9.06 & 90.94 & 1 & Rwanda \\
\hline & 4 & 97.90 & 2.10 & 7.19 & 92.81 & 89.54 & 10.46 & 8.16 & 91.84 & 4 & \\
\hline & 8 & 97.88 & 2.12 & 7.20 & 92.80 & 89.48 & 10.52 & 8.18 & 91.82 & 8 & \\
\hline & & & & & & 77.93 & 22.07 & 24.05 & 75.95 & 1 & South Africa \\
\hline & & & & & & 70.14 & 29.86 & 42.74 & 57.26 & 4 & \\
\hline & & & & & & 69.84 & 30.16 & 45.00 & 55.01 & 8 & \\
\hline & & & & & & 71.04 & 28.96 & 47.45 & 52.55 & 1 & Swaziland \\
\hline & & & & & & 71.37 & 28.63 & 45.25 & 53.75 & 4 & \\
\hline & & & & & & 70.91 & 29.09 & 46.10 & 53.90 & 8 & \\
\hline & & & & & & 97.98 & 2.02 & 1.49 & 85.51 & 1 & Tanzania \\
\hline & & & & & & 97.55 & 2.45 & 1.22 & 98.78 & 4 & \\
\hline & & & & & & 97.53 & 2.47 & 1.11 & 98.89 & 8 & \\
\hline & & & & & & 56.40 & 43.61 & 25.11 & 74.89 & 1 & Uganda \\
\hline & & & & & & 56.43 & 43.57 & 21.64 & 78.36 & 4 & \\
\hline & & & & & & 56.08 & 43.92 & 21.16 & 78.84 & 8 & \\
\hline & & & & & & 75.63 & 24.37 & 28.19 & 71.81 & 1 & Zambia \\
\hline & & & & & & 63.65 & 36.35 & 18.42 & 81.58 & 4 & \\
\hline & & & & & & 63.43 & 36.57 & 16.35 & 83.66 & 8 & \\
\hline & & & & & & 61.51 & 38.49 & 57.00 & 43.00 & 1 & Zimbabwe \\
\hline & & & & & & 57.58 & 42.42 & 72.24 & 27.76 & 4 & \\
\hline & & & & & & 57.89 & 42.42 & 75.61 & 24.40 & 8 & \\
\hline
\end{tabular}

On the other hand, nominal shocks such as demand disturbances seem to have a major influence in explaining real exchange rate movements in the non-CFA countries. They account for more than 30 percent in the RER variability for Nigeria-an oil exporting country, South Africa, Uganda, Zambia and Zimbabwe. The diverse fiscal and monetary policies in the non-CFA countries can explain the increasing important of nominal disturbances in these countries. Moreover, nominal disturbances seem to matter in explaining price level variability in the non-CFA countries in both the short and long run in contrast to the CFA countries. There is a very strict discipline of fiscal and monetary policies in the CFA countries due to the monetary union in these countries. The CFA countries also have a fixed exchange rate system in which their unique currency, the Franc CFA, is pegged to the Euro of the European Union. The fixed exchange rate regime may conceivably limit the role of nominal shocks in the CFA countries where inflation is not a major macroeconomic problem. These results are consistent with findings about developing countries of Asia and Latin America by Hoffmaister and 
Roldós (1996). They conclude that nominal shocks have a small impact on the variability of real exchange rates in Asia and Latin America. They use a panel data consisting of 15 Asian and 17 Latin-American economies.

\section{Conclusion and Policy Implications}

This study investigates the determinants of real exchange rate variability in SSA countries using a structural VAR model over the period 1960-2000. The findings suggest that real shocks play a substantial role in real exchange fluctuations in the CFA countries even in the short run. Nominal disturbances have almost no impacts on the movements of real exchange rates at short and long-term forecasting horizons in the CFA countries. These findings for the CFA countries are consistent with the results of similar techniques applied by other authors to other developing countries in contrast to the findings of the non-CFA countries. In these countries, nominal shocks seem to matter in the RER variability in the short and long run.

The results of this study also show that nominal shocks account for most of the variations in relative prices in the CFA and non-countries in long run. In addition, nominal shocks are important in accounting for the RER fluctuations at short and long-term forecasting horizons in the non-CFA countries. The flexible exchange rate arrangement and the diverse fiscal and monetary policies in these countries could explain the relative importance of nominal shocks in the non-CFA countries.

\section{References}

Bayoumi, T., \& Eichengreen, B. (1994, September). One money and many? Analysing the prospects for monetary unification in various parts of the world. Princeton Studies in International Finance, 76, 1-39.

Blanchard, O., \& Quah, D. (1989, September). The dynamic effects of aggregate demand and supply disturbances. American Economic Review, 79, 655-673.

Chada, B., \& Eswar, P. (1994, October). Are prices countercyclical? Evidence from the G-7. Journal of Monetary Economics, 34, 239-257.

Clarida, R., \& Gali, J. (1994, December). Sources of real exchange rate fluctuations: How important are nominal shocks? Carnegie-Rochester Conference Series on Public Policy, 41, 1-56.

Cumby, R. E., \& Huizinga, J. (1991). Predictability of real exchange rate changes in the short and long run. Japan and the World Economy, 3(1), 17-38.

Dibooğlu, S., \& Koray, F. (2001, April). The behavior of the real exchange rate under fixed and floating exchange rate regimes. Open Economies Review, 12, 123-143.

Dibooğlu, S., \& Kutan, A. M. (2001). Sources of real exchange rate fluctuation in transition economies: The case of Poland and Hungary. Journal of Comparative Economics, 29(2), 257-275.

Dickey, D. D., \& Fuller, W. A. (1981). Likelihood Ratio statistics for autoregressive time series with a unit root. Econometrica, 49, 1057-1072.

Dornbusch, R. (1976). Expectation and exchange rate dynamics. Journal of Political Economy, 84, 1161-1176.

Elbadawi, I., \& Soto, R. (Eds.). (1997). Foreign exchange markets and exchange rate policies in Sub-Saharan Africa and other developing countries. Journal of African Economies, supplementary edition.

Enders, W., \& Lee, B. S. (1997). Accounting for real and nominal exchange rate movements in the post-bretton woods period. Journal of International Money and Finance, 16(2), 233-254.

Flood, R. P., \& Hodrick, R. J. (1986, August). Open Economy business cycles and exchange rate regime choice. National Science Foundation Grant \#SES-8319460.

Fuller, W. A. (1976). Introduction to statistical time series (2nd ed.). New York: Wiley.

Gerlach, H. M. S. (1988). World business cycles under fixed and flexible exchange rates. Journal of Money, Credit, Banking, 20(4), 621-632.

Hoffmaister, A. W., \& Roldós, J. E. (1996a). Are business cycles different in Asia and Latin America? International Monetary Fund. 
Hoffmaister, A. W., \& Roldós, J. E. (1996b). The sources of macroeconomic fluctuations in developing countries: Brazil and Korea. International Monetary Fund Working Paper No. WP/96/20, 1-19.

International Monetary Fund. (2001). International Financial Statistics, CD-ROM, 2001, International Fund, Washington, D.C.

Kwiathowski, D., Phillips, P. C. B., Schmidt, P., \& Shin, Y. (1992). Testing the null hypothesis of stationarity against the alternative of a unit root. Journal of Econometrics, 54, 159-178.

Lastrapes, W. D. (1991). Sources of fluctuations in real and nominal exchange rates. The Review of Economics and Statistics, 530-539.

Meese, R., \& Rogoff, K. (1988, September). Was it real? The exchange rate-interest differential relation over the modern floating-rate period. Journal of Finance, 43(4), 933-948.

Mussa, M. (1986). Nominal exchange rate regimes and the behaviour of real exchange rates: Evidence and implications. Carnegie-Rochester Conference Series on Public Policy, 26, 117-134.

Obstfeld, M. (1985). Floating exchange rates: Experience and prospects. Brookings Papers on Economic Activity, 2, 369-450.

Savvides, A. (1996). CFA Franc zone membership and exchange rate variability. Journal of African Economies, 5(1), 52-68.

Sekkat, K., \& Varoudakis, A. (2000). Exchange rate management and manufactured exports in Sub-Saharan Africa. Journal of Development Economics, 61, 237-253.

Shapiro, M. D., \& Watson, M. W. (1988). Sources of business cycle fluctuations in NBER macroeconomics annual 1988 (pp. 111-148) (S. Fischer, Ed.). Cambridge, M.A.: MIT Press. 